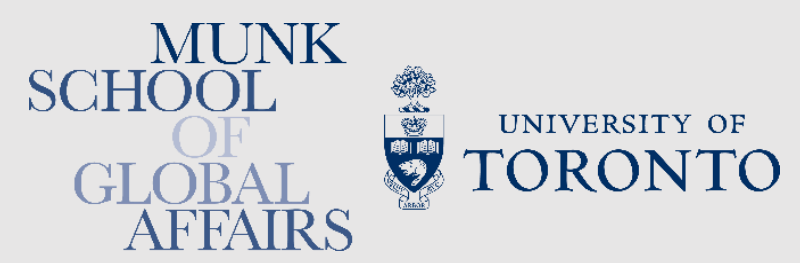

\title{
TOWARD A THEORY OF SOCIAL \\ INNOVATION
}

Kristen Pue, Christian Vandergeest, and Dan Breznitz 


\section{Executive Summary}

The term social innovation has become popular as an umbrella concept describing an array of social programs and initiatives deserving attention. Unfortunately, this flurry of social innovation activity has, as of yet, not led to the development of a comprehensive theory of social innovation. This is a critical missing step if our aim is to enact public and private policies to develop, stimulate, and maximize social innovation. Tellingly, we have yet to agree on a definition: there is no unified sense of what social innovation is and what is it not. Without a clearer idea of cause and effects in social innovation, it will remain difficult to develop desirable interventions and scale them up.

This paper is a first step to close this gap; our aim is to offer a theoretical framework which can easily be used in practice. We start by proposing a new definition of social innovation, characterizing it as a process encompassing the emergence and adoption of socially creative strategies, which reconfigure social relations in order to actualize a given social goal. This definition offers several advantages. First, by defining social innovation as a process aiming to bring about social change we avoid two main deficiencies of current definitions. First, we do not tautologically define social innovation as its own outcome. Second, we refrain from making it normative, which is important because we can easily envision a successful implementation of a social creative strategy that aims to improve social conditions and has successfully brought significant social chance, only to find that the outcome leaves the target population worse off. A second advantage of defining social innovation as a process is that it enables us to easily delineate between the main actors, their institutional environment, and the interactions between them. This foundational framework will enable researchers to develop hypotheses and test them while simultaneously providing a basis for policy makers to develop policies rooted in an understanding of cause and effect, analysis of bottlenecks, and a deepened appreciation as to where policy can or cannot have a positive impact.

Our framework is built so as to integrate several components of existing research on social innovation, extending their utility for both research and practice.

The socially creative strategy is a key reactant in the process of social innovation; the invention of a socially creative strategy initiates social innovation, yet the transformation of a socially creative strategy occurs throughout the social innovation process. While a socially creative strategy may not, for a variety of reasons, complete the social innovation process by arriving at the end state of adoption, a completed social innovation process will always result in social change. This outcome occurs due to the interaction of the two driving forces of social innovation. We call these driving forces of social innovation the agentic engine and the structural engine. The terms 'agentic' and 'structural' reflect social science thinking on how individuals (agents) can influence events but are also constrained in doing so by social structures such as rules, roles, and organizations.

Broadly, the process of social innovation proceeds as follows. The agentic engine of social innovation begins when a social entrepreneur (or group of social entrepreneurs) 
devises a socially creative strategy to put into practice an idea that reconfigures society's approach to a given social problem. The social entrepreneur is influenced by the social environment and existing social structures. The structural engine of social innovation pertains to whether the uptake of a socially creative strategy occurs across the social environment and social structures. This occurs through emergence and adoption, two halves of the social innovation diffusion cycle. If both engines of social innovation lead to the successful emergence and then adoption of a socially creative strategy (the end state of the social innovation process), they result in two outcomes: social change and a reconfiguration of the social problem such that it, ideally though not necessarily, meets its social goal.

Throughout the paper we elaborate on this concept and show its practical use. Following the introduction we define social innovation and elaborate on the core elements of this definition in section II. We continue in section III by presenting our framework for understanding the process of social innovation, bringing together concepts from related research areas. We discuss how the process of social innovation may differ according to the institutional context and the three policy objectives commonly associated with social innovation. Next, in section IV we justify three novel aspects of our approach. Finally, we conclude in section $\mathrm{V}$ by considering how our approach is valuable for scholars and practitioners. 


\section{Table of Contents}

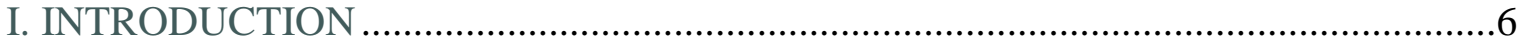

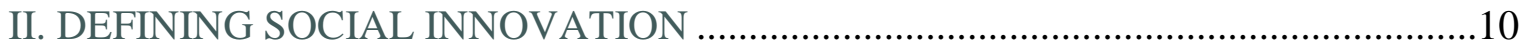

III. THE SOCIAL INNOVATION PROCESS ...................................................... 13

A. The Agentic Engine of Social Innovation ....................................................... 15

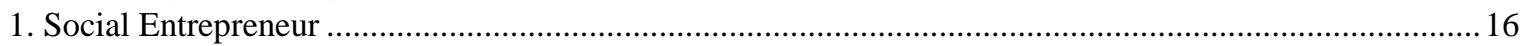

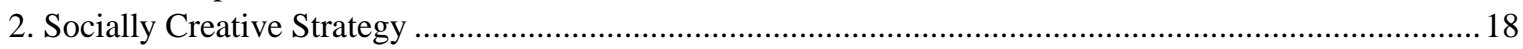

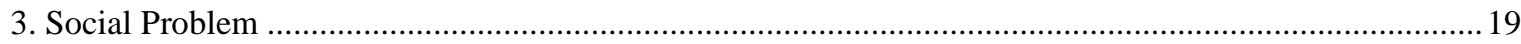

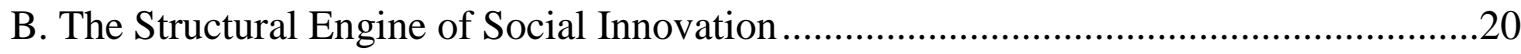

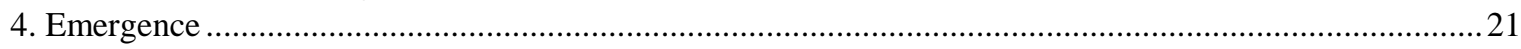

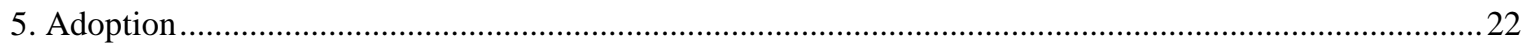

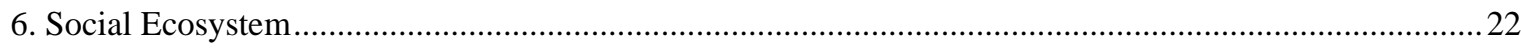

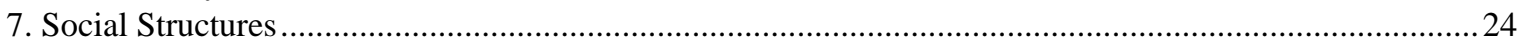

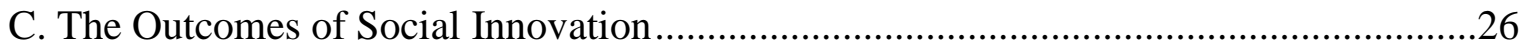

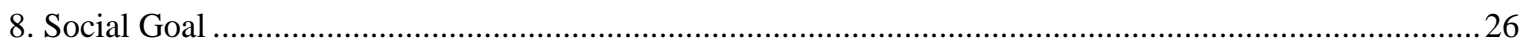

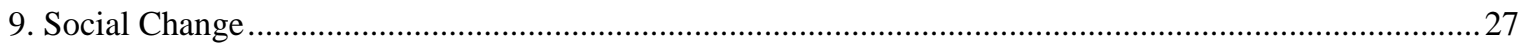

D. The Institutional Contexts of Social Innovation ...............................................2

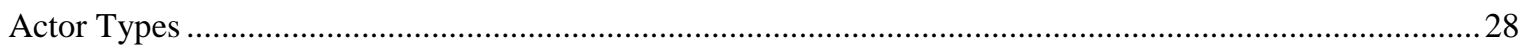

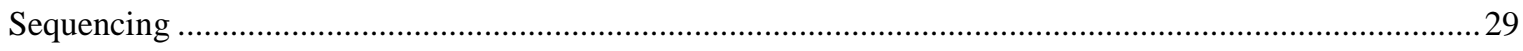

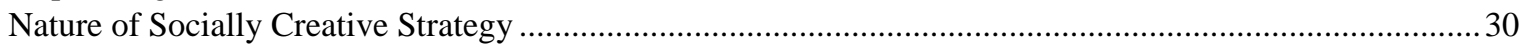

E. The Policy Goals Served by Social Innovation .................................................. 31

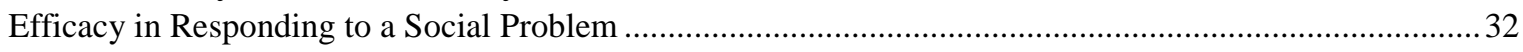

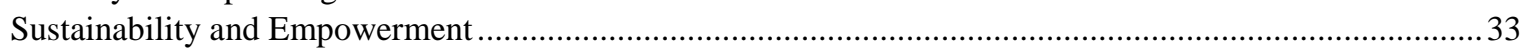

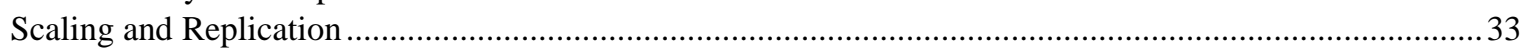

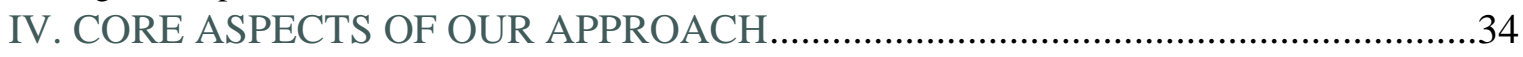

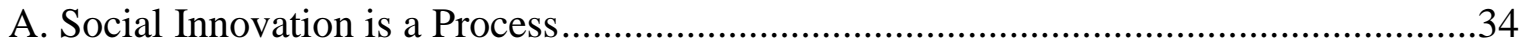

B. Social Innovation Need Not Deliver a Social Benefit.............................................37

C. Social Innovation is Driven by the Interaction of Agents and Social Structure, Not an

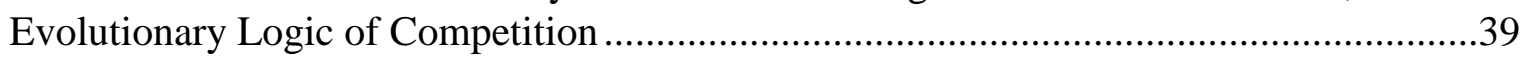

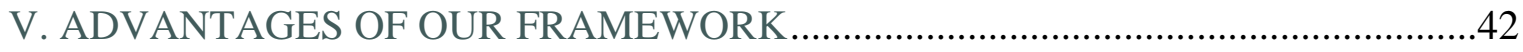

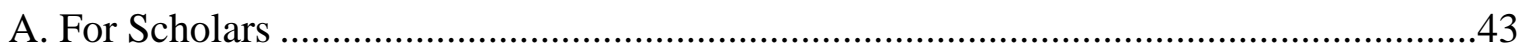

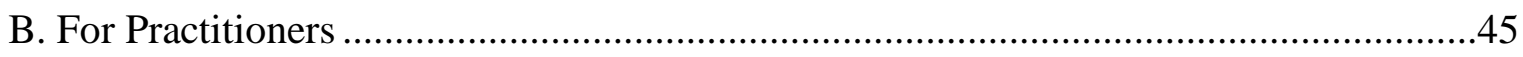

APPENDIX 1: MODULARITY ANALYSIS OF THE SCHOLARLY SOCIAL ...........49

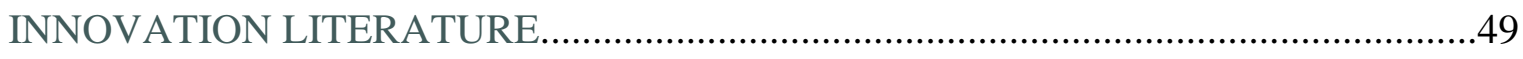

i. No single disciplinary approach dominates the SI literature, although business economics contributed a clear plurality of results

ii. Five distinct communities of research exist in the SI literature and are characterised by

a high degree of inter-citation by a small number of authors .....................................49

iii. The SI literature is fragmented, as the five research communities emanate from distinct disciplinary traditions and are only loosely connected by citations ......................50 
iv. Some highly cited articles were not strongly tied to any of the dominant research

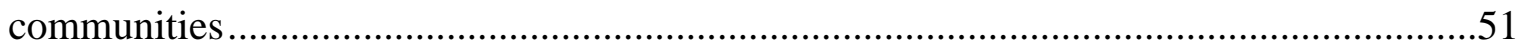

APPENDIX 2: SOCIAL INNOVATION IN PUBLIC DISCOURSE ...........................53

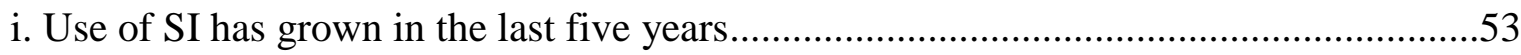

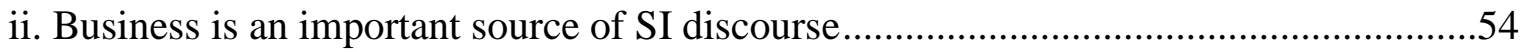

iii. Few of the texts returned in the search were from civil society groups ......................55

iv. The European Union is well represented in SI discourse .........................................55

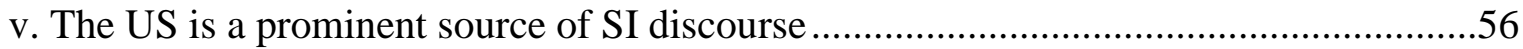

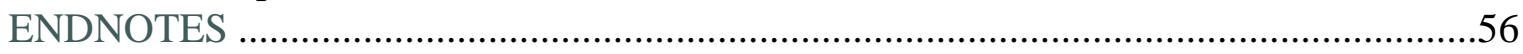




\section{INTRODUCTION}

Social innovation has a long history, ${ }^{1}$ but the term has rapidly amassed popularity recently as an umbrella concept describing an array of social programs and initiatives deserving attention. ${ }^{2}$ Many governments have established policies for social innovation, often with the stated aim of encouraging creative solutions to difficult challenges. For example, the European Union launched a European Social Fund; the U.S. White House established an Office of Social Innovation and Civic Participation; and the Government of British Columbia created a Ministry of Social Development and Social Innovation. Most recently, Prime Minister Justin Trudeau directed the Minister of Families, Children, and Social Development and the Minister of Employment, Workforce Development, and Labour to develop a Social Innovation and Social Finance strategy. The voluntary and private sectors are equally active on the issue of social innovation. Businesses frequently describe their social responsibility activities as social innovation - to such a degree that some argue corporate social innovation is the new corporate social responsibility. ${ }^{3}$ In the voluntary sector, nonprofit, social enterprise, and charitable service providers increasingly seek to be socially innovative in approaching their missions. One example is the International Committee for the Red Cross and Red Crescent (ICRC) Red Innovation program. $^{4}$

Unfortunately, this flurry of social innovation activity has not been based on sound theoretical foundations. As practice, social innovation is frenetic: the term is deployed for several purposes and carries a variety of connotations, leaving one a bit unclear on its 
precise meaning (aside from perhaps being synonymous with 'good and new'). ${ }^{5}$ The result has been the propagation of laundry lists, with little examination of the mechanisms underlying social innovation. ${ }^{6}$ This limits policy efficacy because absent a strong foundational knowledge of how social innovation operates one cannot hope to identify how interventions, trade offs, and externalities interact and, hence, how to effectively develop and implement successful social innovation policies.

Given the myriad public and private resources channeled toward social innovation, it is important to understand what social innovation is, how it works, and its policy outcomes. Unfortunately, research has thus far failed to provide a robust and coherent framework theory of social innovation on which policy and practice can be based. This is chiefly a result of the fragmentation of the study of social innovation into multiple, largely selfcontained, fields. Tellingly, the definition of social innovation remains contested, which means that we have yet to agree on what social innovation is - let alone its real and aspirational impacts. ${ }^{7}$ As most scholars and practitioners acknowledge, "there is no consensus regarding its relevance or specific meaning". 8

The inability to clearly define social innovation has proven to be a core obstacle in the study of social innovation, as conceptual clarity is integral to the establishment of a progressive research agenda. Until scholars and practitioners can work from a shared understanding of the term that they are using, it will be impossible to engage across research communities in meaningful ways. Therefore, advancing cross-disciplinary study of social innovation will remain an unattainable goal. 
We undertook a modularity analysis of social innovation in order to identify the contours of academic study on this important topic. Our data confirmed that, despite the recent growth of strong social innovation research, the literature remains highly fragmented. The modularity analysis yielded five distinct social innovation research communities (see Appendix 1). Within each social innovation research community, rich dialogue has resulted in some convergence on the meaning of social innovation and how to study it. However, between approaches there exists a widening divide even as the academic study of social innovation has matured. We propose that bridging the divide between these areas can strengthen each. Doing this requires fashioning a conceptual framework that is cognizant of the foundational propositions of each social innovation research community, whether it incorporates or excludes specific propositions. It is also critical that a framework for studying social innovation is structured so as to accommodate the specific phenomena under study in each of the research communities.

Exacerbating the problem of fragmentation, the academic literature has remained too far removed from practice in its treatment of social innovation. Although social innovation research communities have produced robust studies, case analyses remain largely post hoc descriptions of how and whether a policy or project was socially innovative. ${ }^{9}$ While such studies are useful in identifying characteristics and signifiers of social innovation, little theoretical work has been done on how one might identify, cultivate, and replicate socially creative interventions through existing institutions. This deficiency limits policy applicability. A forward-thinking theory of social innovation is needed, one that brings academic study - all disparate communities of research on social innovation - and 
practice together. In this paper we seek to rectify the current gap by presenting a policyrelevant framework for conceptualizing social innovation, one that is social at its core. We begin by proposing a new definition of social innovation, characterizing it as a process encompassing the emergence and adoption of socially creative strategies that reconfigure social relations in order to actualize a given social goal. This definition offers the advantages of: i) defining social innovation as a process; ii) including socially creative strategies as a key reactant in the process of social innovation; iii) not defining the phenomenon by the outcome (i.e., requiring that only actions that ended with a social benefit be defined as social innovation); and iv) including social change as a necessary outcome of social innovation. Part I of the paper elaborates on this definition and its usefulness.

Building on our definition, in Part II we present a framework for understanding social innovation as a process driven by the interaction of its two engines: an agentic engine and a structural engine. First, the agentic engine of social innovation begins when a social entrepreneur devises a socially creative strategy to put into practice an idea that reconfigures society's approach to a given social problem. Second, the structural engine of social innovation pertains to how society responds: whether the uptake (emergence and adoption) of a socially creative strategy occurs across the social environment and social structures. This occurs through emergence and adoption, two halves of what we might term the social innovation diffusion cycle. If the socially creative strategy completes this social innovation diffusion cycle, two outcomes result: social change and a reconfiguration of the social problem such that it, ideally, meets its social goal. Actors 
Innovation Policy Lab White Paper 2016-01

may promote social innovation in order to advance at least one of three policy objectives: efficacy in responding to a social problem; sustainability and empowerment; and scaling and replication.

This framework describes the process of social innovation in general terms. However, being more specific about the social innovation process requires identifying the institutional context in which it takes place. We propose that three variables relating to institutional context influence the process of social innovation: actor types, sequencing, and the type of socially creative strategy undertaken.

Our proposed framework differs in several respects from mainstream thinking on social innovation. Accordingly, in Part III, we justify three novel aspects of our approach using a process definition of social innovation, not requiring the delivery of social benefit as a condition of social innovation, and identifying a structural and agentic engine - in light of the existing social innovation literature. Building on these justifications, Part IV explains the benefits of our approach for both scholars and practitioners.

\section{DEFINING SOCIAL INNOVATION}

We define social innovation as a process encompassing the emergence and adoption of socially creative strategies that reconfigure social relations in order to actualize a given social goal. Several characteristics of this definition are worth noting.

First, this definition presents social innovation as a process. The term 'process' describes a set of connected events or actions occurring according to given rules and parameters. ${ }^{10}$ Conceptualized as a process, social innovation encapsulates the series of steps and 
changes happening as a socially creative strategy progresses (or not) toward the end state of adoption. ${ }^{11}$ Social innovation is not a defined end state nor is it the socially creative strategy itself. Instead, we contend that social innovation is a process driven by two 'engines': an agentic engine and a structural engine. ${ }^{12}$ The terms 'agentic' and 'structural' reflect social science thinking on how individuals (agents) can influence events but are also constrained in doing so by social structures such as rules, roles, and organizations. In this sense, the agentic engine refers to the actions and purposes of the individual or group of individuals within the process of social innovation. Broadly, it consists of a value orientation or purpose that motivates an individual to develop a particular socially creative strategy. The structural engine, which is similar to the concept of institutionalization, includes: the background framework that shapes the content and strategic choices undertaken by socially creative actors and then the mechanisms by which these socially creative strategies are produced and reproduced (or not) over time. Second, the process of social innovation concerns the emergence and adoption of socially creative strategies. The socially creative strategy is a key reactant in the process of social innovation; the invention of a socially creative strategy initiates social innovation, yet the transformation of a socially creative strategy occurs throughout the social innovation process. Accordingly, the process of social innovation cannot begin in absence of a socially creative strategy. The remaining two elements of our social innovation definition should be read as defining characteristics of socially creative strategies. To constitute social innovation, the socially creative strategy must be targeted at reconfiguring social relations toward the goal of creating social benefit. 
By the reconfiguration of social relations we mean that a socially creative strategy must in some way change how people interact with one another with regards to a given issue. This might involve the invention of a different institution, for example through the Grameen Bank's introduction of microcredit (in the form of small loans offered to borrowers that ordinarily would not qualify because they lack collateral, a credit history, and steady employment). ${ }^{13}$ It could also pertain to a change of social norms or roles, for example through a program that trains hairdressers to recognize signs of domestic abuse in their clients and to respond appropriately by providing information to these patrons on how to seek help. ${ }^{14}$ Reconfiguring social relations requires that the socially creative strategy involves somehow changing the interactions between individual human beings in some way that is linked to a given social problem. As such, while a project that encourages the use of bed nets as a malaria-prevention tool might be considered a socially creative strategy, the invention and production of antimicrobial bed nets, by itself, would not.

A socially creative strategy must also aspire to attain a social goal. That is, a given program or initiative must be a 'solution' to a 'problem' that affects an identified community. Within these parameters, social goals can be defined in any number of ways. We have included this requirement not only as a reflection of the policy goals underlying the practice of social innovation, but also because this public role of socially creative strategies renders the process of social innovation relevant to governance more broadly. As such, we can expect the process of social innovation to be different than, say, market innovation. 
Innovation Policy Lab White Paper 2016-01

Third, delivering social benefit is not a requirement of our definition of social innovation. As noted above, our definition requires that a socially creative strategy have the intent to use social practices to tackle social problems - which is to say that the socially creative strategy is problem-driven. It does not require that actors involved in social innovation be acting altruistically. ${ }^{15}$ Furthermore, our definition does not imply that the outcome would improve society or deliver a social benefit, even if the strategy is successful adopted. A misguided socially creative strategy, even if adopted across a social system, could fail to improve social conditions and may even produce harmful results. It would nonetheless have undergone the process of social innovation.

Finally, social change is a necessary outcome of social innovation. While a socially creative strategy may not, for a variety of reasons, complete the social innovation process by arriving at the end state of adoption, a completed social innovation process will always result in social change. As discussed further below, this outcome occurs due to the interaction of the two driving forces of social innovation: the agentic engine and the structural engine.

\section{THE SOCIAL INNOVATION PROCESS}

Social innovation is a process of change driven by an agentic and a structural engine. This section provides an explanation of how the social innovation process unfolds through a description of these two engines. The process that we outline draws upon and integrates existing social science research, as well as work on social innovation from each 
of its research communities, in order to create a coherent macroscopic framework connecting these distinct threads.

Broadly, the process of social innovation proceeds as follows. The agentic engine of social innovation begins when a (1) social entrepreneur (or group of social entrepreneurs) devises a (2) socially creative strategy to put into practice an idea that reconfigures society's approach to a given (3) social problem. The social entrepreneur is influenced by the (6) social environment and (7) existing social structures. The structural engine of social innovation pertains to whether the uptake of a socially creative strategy occurs across the (6) social environment and (7) social structures. This occurs through (4) emergence and (5) adoption, two halves of what we might term the social innovation diffusion cycle. If both engines of social innovation lead to the successful emergence and then adoption of a socially creative strategy (the end state of the social innovation process), they result in two outcomes: (9) social change and a reconfiguration of the (3) social problem such that it, ideally, meets its (8) social goal. The sections below explain, in further detail, the dual engines of social innovation as well as its outcomes. 


\section{AGENTIC ENGINE}

1. Social Entrepreneur
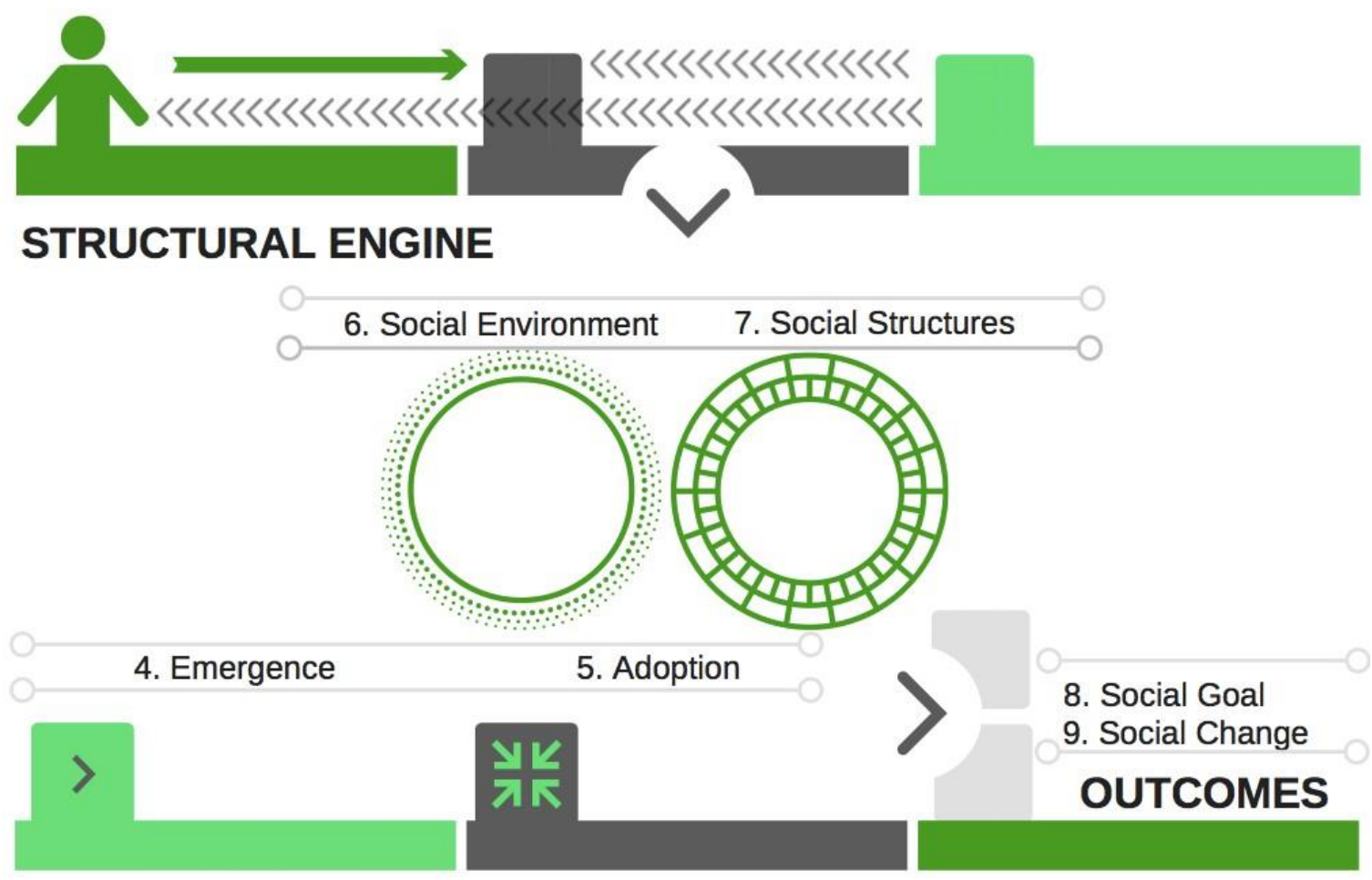

A. The Agentic Engine of Social Innovation

The agentic engine of social innovation begins when a (1) social entrepreneur (or social entrepreneurs, either individuals or organizations) devises a (2) socially creative strategy - that is, when an actor, driven by a particular (A) motivation and possessing a set of (B) values, draws on his (C) individual faculties (i.e. creativity, knowledge, and experience) to put into practice an idea which reconfigures society's approach to a given (3) social problem. The idea designed by the actor may take various forms, such as a new service to be delivered to a target community or a norm change. The social entrepreneur is influenced by the (6) social environment and (7) existing social structures, which may shape the opportunities available to him as well as his social purpose and values (through, 
for example, the influence of intersubjectively held background norms). ${ }^{16}$ Below, we elaborate on the core elements of the agentic engine of social innovation: the social entrepreneur, the socially creative strategy, and the social problem. Our aim in so doing is to introduce the reader to existing works on these concepts and to explain how these concepts fit into the broader context of social innovation.

\section{Social Entrepreneur}

Although the narrative of the adventurous social entrepreneur who single-handedly devises and implements his socially creative strategy is too simplistic, the concept of a social entrepreneur is relevant for the study of social innovation for at least two reasons. First, it provides a unit of analysis connecting studies on creativity to the process of social innovation. Second, it emphasizes the role of agents throughout the social innovation process. As such, we include the social entrepreneur as an element of our framework. Arriving at measurable characteristics that define an entrepreneur generally, and a social entrepreneur in particular, remains an elusive task. ${ }^{17}$ For the purposes of this paper, however, it is sufficient to define a social entrepreneur as the prime mover in the social innovation process. ${ }^{18}$ With respect to social innovation, a social entrepreneur is simply the actor that develops a socially creative strategy to solve a social problem and may advance that socially creative strategy as it moves toward emergence and adoption. ${ }^{19}$ Notably, in many cases of social innovation the social entrepreneur may not be involved in emergence or adoption, as discussed further below. The large and growing social entrepreneurship literature has sought to identify the drivers of social entrepreneurship at 
the macro-level (i.e. socio-economic factors ${ }^{20}$ ), meso-level (i.e. opportunity ${ }^{21}$ and social networks ${ }^{22}$ ), and micro-level (i.e. motivations, ${ }^{23}$ intentions, ${ }^{24}$ and traits ${ }^{25}$ ). Thus, there is a good deal of existing information on how to identify and encourage socially entrepreneurial individuals and organizations.

Regarding the role of the social entrepreneur in the process of social innovation, three related concepts are worth mentioning: motivation, values, and individual faculties of the actor.

A. Motivation: in principle, an actor can be animated by any purpose or value orientation in designing a socially creative strategy. ${ }^{26}$ Motivation is multifaceted and may include social or personal factors. Often, it involves both an intrinsic element (such as curiosity, self-expression, and contribution to others) ${ }^{27}$ and an extrinsic element (based on rewards such as praise or status). ${ }^{28}$ Understanding how social entrepreneurs are motivated may present one avenue for encouraging the incidence of social innovation, especially as regards extrinsic motivations. For example, extrinsic rewards can be motivating but in some cases may distract from the creative process. ${ }^{29}$

B. Values: all individuals ascribe to values, which are culturally defined standards by which people judge desirability and goodness ${ }^{30}$ and which serve as guiding principles of behavior that influence attitudes, norms, and beliefs. ${ }^{31}$ Values shape the motivation of the social entrepreneur (especially regarding selection of the social problem toward which a socially creative strategy is directed), as well as how the social problem toward which a social entrepreneur directs his activities is understood. Additionally, values may be changed by social innovation. ${ }^{32}$ 
C. Individual faculties: any socially creative strategy must be fashioned by an actor that is motivated to act creatively to reconfigure the response to a social problem, as that actor perceives it. It is an act of ingenuity that may be more or less likely to be undertaken by some actors than others. This requires attention to the individual faculties of the actor, in terms of personality traits and skills as well as macro-level characteristics such as their socio-economic status or organizational affiliation. ${ }^{33}$

\section{Socially Creative Strategy}

A socially creative strategy is an original or imaginative idea (i.e. a plan of action or policy) designed to achieve an objective relating to society or its organization. With regards to social innovation, a socially creative strategy must be targeted at reconfiguring social relations toward the goal of creating social benefit. It is created by an individual(s) or organization(s) and may be a new intervention ${ }^{34}$ (i.e. a new service to be delivered) or a targeted norm change. ${ }^{35}$ As with market innovation, a socially creative strategy may be entirely novel or may arise from the recombination or transmission of an existing idea to a new context. Additionally, socially creative strategies may result from collaboration. ${ }^{36}$ While a socially creative strategy is a key reactant in the process of social innovation, it also undergoes change throughout: for example, once identification of the idea for a socially creative strategy has taken place, the actor engages in prototyping and experimentation. ${ }^{37}$ There has been much written on how ideas should best be tested and implemented, generally and specifically within the context of social ventures. ${ }^{38}$ Further, it 
is worth noting that the social innovation process may require that a socially creative strategy be advanced through many socially creative tactics. ${ }^{39}$

Finally, although socially creative strategies can pertain to a variety of activities, they must in some way involve reconfiguration of a social practice. This means that the socially creative strategy must seek to change or rearrange the rules, roles or routines pertaining to a particular pursuit. For example, a socially creative strategy targeted at curbing endemic cocaine use by Alberta oil sands workers might seek to change incentives for weekend drug use through making cocaine a less attractive option by reconfiguring routine workplace drug testing procedures and developing a test for marijuana use that is sensitive only to very recent intake of marijuana. ${ }^{40}$ This would constitute a socially creative strategy, in contrast to, say, the invention of pee repellant paint. ${ }^{41}$ While pee repellant paint aims to change human behavior, it does not change social relations. This differs from other strategies to resolve the same problem, such as the use of pee whistleblowers and drummers or walls of shame, as have emerged in India, ${ }^{42}$ which aim to alter the social relations surrounding public urination and, therefore, can be described as socially creative strategies.

\section{Social Problem}

Socially creative strategies address social problems, which are individually and intersubjectively defined. First, the actor must believe that a social problem exists, and that the socially creative strategy will meet a goal pertaining to that problem. Second, for the socially creative strategy to advance through the social innovation process it must 
also be intersubjectively identified as a social problem: others must also agree that the social problem exists and about its causes. A socially creative strategy could also be targeted at identifying something as a social problem. In this case, gaining intersubjective agreement about the social problem would be the core objective of the socially creative strategy.

\section{B. The Structural Engine of Social Innovation}

Once a socially creative strategy is identified through an exercise of agency it must, in order to enact change, be produced and reproduced over time via the structural engine of social innovation. The structural engine of social innovation, then, pertains to whether the uptake of a socially creative strategy occurs through the two distinct, but interrelated, avenues of institutionalization: the (6) social ecosystem and (7) social structures. This occurs through (4) emergence and (5) adoption, two halves of the social innovation diffusion cycle. Emergence is the stage in which a (1) social entrepreneur gains access to an organizational platform for the promotion of his (2) socially creative strategy, enabling early adoption of the socially creative strategy, for example through a pilot program or endorsement by norm leaders. The socially creative strategy may be developed via prototyping or experimentation as emergence takes place. Adoption pertains to the wider implementation of a socially creative strategy such that it reaches the target audience. This can also be termed the 'institutionalization' of the socially creative strategy. Generally, the literature has identified two directions of institutionalization: top-down and bottom-up. While these analytical concepts are a bit simplistic, they are useful 
insofar as they direct one to the key point that the process of adoption depends greatly on the institutional context. This point is discussed in further detail in Section III D. For the moment, however, it will suffice to discuss in general terms how socially creative strategies might be adopted either in a top-down process or a bottom-up process. In the top-down process, the socially creative strategy is embedded in institutional frameworks by relevant authorities; in the bottom-up process, the socially creative strategy becomes accepted by society and, eventually, may attain taken-for-granted status (internalization). The section below discusses further the core elements of the structural engine of social innovation: emergence, adoption, the social ecosystem, and social structures.

\section{Emergence}

Emergence is the beginning of social innovation diffusion cycle. It consists of the process by which social entrepreneurs gather initial support for their socially creative strategy by acting as relationship builders and brokers. ${ }^{43}$ At this point in the social innovation process, support from within the social ecosystem is sought to provide initial materials for developing the socially creative strategy, as well as participation to test its implementation. The characteristic mechanism of this stage is persuasion by social entrepreneurs (or other actors) who use their position within the social ecosystem, as well as existing social structures, strategically in an attempt to convince others to embrace the socially creative strategy. ${ }^{44}$ Specifically, the social entrepreneur seeks an organizational platform through which to promote the socially creative strategy and to attain early adopters. $^{45}$ 


\section{Adoption}

If emergence successfully occurs, the social innovation diffusion cycle may move forward to the adoption phase of the social innovation process. Adoption is the institutionalization of a socially creative strategy across the social system more widely. As such, it involves the revision of expected practice, learning, and perhaps even the internalization of new identities and interests. ${ }^{46}$ There are two primary logics at play in the adoption phase: top-down institutionalization and bottom-up institutionalization. Topdown institutionalization consists of entering into "relatively stable and sustainable arrangements with the public administration". ${ }^{47}$ Bottom-up institutionalization, in contrast, entails penetrating the public sphere and informing public discourse and practice. The precise requirements of each type of institutionalization will vary according to the socially creative strategy and its institutional context. Broadly, the adoption phase begins with mobilization of the socially creative strategy across a wider social space. It may involve scaling up pilot initiatives. If a socially creative strategy proceeds in adoption, it may eventually achieve a cascade, in which the socially creative strategy is socialized as common practice. ${ }^{48}$ Finally, a socially creative strategy may be internalized, achieving a taken-for-granted status. ${ }^{49}$

\section{Social Ecosystem}

There is no neat dividing line between social structures and the social ecosystem. Indeed, structures form an important element of any social ecosystem, as they constitute patterns 
of social relations that create reliable expectations regarding social action. Nonetheless, we posit that it is worth dividing these two concepts as an analytical matter in order to more cleanly delineate two distinct mechanisms at play in the uptake of social innovation. The first, discussed here under the social ecosystem, concerns networks and personal ties upon which actors might draw in promoting a socially creative strategy. The second, which we describe below under the heading of social structure, relates to the extent to which existing institutions might disproportionately empower certain actors relative to others - especially regarding control over material resources - affecting emergence and adoption.

A social ecosystem comprises the complex network of interacting individuals in a given social space; it is the physical and cognitive area within which members of a community interact, as well as the individuals and groupings themselves. As such, the social ecosystem is relevant to the process of social innovation in many ways. The social entrepreneur develops a socially creative strategy within a social ecosystem and actors promoting this socially creative strategy draw upon aspects of this ecosystem throughout. Social problems arise within a social ecosystem, are defined as problems within this space, and are framed in light of cognitive boundaries within and amongst social ecosystems. The target audience of a socially creative strategy is found within a particular social ecosystem, and actors within this space play a role in determining whether a socially creative strategy advances to emergence and adoption (or not). Accordingly, several concepts that are commonly evoked in the social innovation literature can be considered as aspects of the social ecosystem. Below, we describe some relevant 
concepts that have been discussed by the social innovation literature. It should be stressed that the aim here is to highlight how one might fit these concepts into our framework theory: we do not aim to take a position on contentious topics such as social capital. The first concept from the social innovation literature that fits under the social ecosystem includes networks: collectivities of interpersonal ties. Such ties, whether weak or strong, play a role in the diffusion of ideas and practices across social spaces. ${ }^{50}$

Second, the social ecosystem encompasses identity- and role-based social groupings. ${ }^{51}$ This includes organizations - arrangements of people for a particular purpose - and their aggregation into organizational fields. ${ }^{52}$ Third, social capital is a product of the social ecosystem. Although this term remains hotly contested in the literature, it can generally be viewed as networks that facilitate cooperative action, often related to trust. ${ }^{53}$ Social capital is characteristically discussed as a resource that can be individually possessed and deployed, but it can also be described as 'social glue' that binds, bonds, and links society. ${ }^{54}$ Such relations create a common sense of identity but also generate a social hierarchy; in this sense, social capital may also pertain to one's position within such structures. ${ }^{55}$ Finally, the social ecosystem is the space within which social entrepreneurs are embedded, and hence highlights the important link between social innovation and geography that has been emphasized through concepts such as community and localism (which urges acknowledgement of the role of local resources). ${ }^{56}$

\section{Social Structures}


Above we have identified the diffuse array of linkages that bind individuals within a society. Focusing on social structures guides thinking about how the patterns formed by these linkages establish the basis of widespread practice, which establish sources of power. A social structure is a pattern of social interactions identifiable at a given moment. ${ }^{57}$ The concept of social structure describes how social life is affected by the constellation of material capabilities, ideas, and institutions, ${ }^{58}$ accordingly, it directs attention to power. ${ }^{59}$

Social structures are relevant to social innovation in several respects. For example, the process of social innovation is shaped by existing authorities; the institutional arrangements that structure social relations; and background norms pertaining to a social problem and the proposed solution. ${ }^{60}$ The social structure most often discussed in the study of social innovation is the institution. ${ }^{61}$ Institutions are the rules of the game; ${ }^{62}$ they constitute stable mutual expectations that both enable and constrain actors. This may include practices; ${ }^{63}$ identities and interests $;{ }^{64}$ constitutive, regulative, and procedural norms $;{ }^{65}$ organizations, rules and routines; ${ }^{66}$ or any other arrangement that prescribes, proscribes, and/or authorizes behavior. ${ }^{67}$ Although institutions can be created and modified through actions of individuals or groups of individuals, institutions also imply a hierarchy of influence (giving some actors greater power to influence than others). ${ }^{68}$ Institutional theory offers "a way of thinking about formal organization structures and the nature of the historically grounded social processes through which these structures develop." 99 


\section{The Outcomes of Social Innovation}

If the process of social innovation arrives at its end state, the adoption of a socially creative strategy, it results in two outcomes: (9) social change and a reconfiguration of the (3) social problem such that it, ideally though not necessarily, meets a (8) social goal. Below, these outcomes are expanded upon.

\section{Social Goal}

A completed process of social innovation may meet a social goal: the objective toward which the socially creative strategy was directed may be fulfilled and the outcome might be a social improvement. There are, however, several reasons to expect that a socially creative strategy may be successfully adopted without improving society. First, propositions about the causes of a particular social problem may be mistaken; in this case, even if the new approach is uniformly undertaken, better outcomes will not materialize. Second, negative externalities may result from the new practice or intervention. As such, while the process of social innovation results in the reconfiguration of a social problem it may not deliver a 'social benefit,' and might even make conditions worse. For example, some have argued that micro-loan programs harm society, as the majority of impoverished beneficiaries end up with less incremental income after receiving a micro-loan. ${ }^{70}$ Although micro-loans comprise a commonly cited instance of social innovation, it is not agreed that they deliver social benefit. As another example, the social impact bond ${ }^{71}$ is a financial tool for funding preventative social programs. There 
has been fierce debate on whether it is a helpful or harmful socially creative strategy since it was invented in $2010 .^{72}$

\section{Social Change}

In addition to consequences affecting the target social problem, the reconfiguration of society's practices on a particular issue (which occurs through the process of social innovation) also changes the broader social environment. For instance, the adoption phase of social innovation may bring together and mobilize groups, creating a new social role or changing existing role relations. ${ }^{73}$ As an example, Wheeliz, one of the winners of the 2015 European Social Innovation Competition, created a French car share application specifically set up for vehicles that are disability adapted in order to improve access to mobility for physically disabled persons. This intervention brings together a group of people that were not previously connected. ${ }^{74}$ This aspect of social innovation (precipitation of wider changes in the organization of society) has been studied at-length by the resilience literature, with its roots in complexity theory, which views social innovation as an instantiation of the reorganization that must occur within a resilient social system. ${ }^{75}$ Depending on the nature of the socially creative strategy and scale of uptake, social innovation is considered to be transformative or adaptive change. ${ }^{76}$ Resilience theorists argue that social innovation can greatly increase the resilience of a particular social environment by providing the 'refresh' that is needed. ${ }^{77}$

\section{The Institutional Contexts of Social Innovation}


Above, we have described the process of social innovation in general terms. But, as noted above, the institutional context affects the process of social innovation itself; being more specific about the social innovation process requires identifying the institutional context in which it takes place. We posit that three variables relating to institutional context influence this process: actor types, sequencing, and the type of socially creative strategy undertaken. In this section, we describe these variables and offer examples to illustrate how one might operationalize the variables and sub-variables in case studies on social innovation. It should be stressed that our thinking on this is preliminary; we present these variables in order to stimulate further thought on how the institutional context affects the social innovation process.

\section{Actor Types}

It is important to recognize that a single social entrepreneur is not always, or even often, the key actor across the four points of the social innovation process. Instead, actor types commonly change throughout the social innovation process, especially at four points: problem identification, solution identification, emergence, and adoption. For example, the housing first strategy for addressing homelessness is a socially creative strategy first identified by academia and promoted by non-profit organizations. It has since emerged through trial implementation by the Canadian federal government ${ }^{78}$ and has been adopted in homelessness strategies by municipal governments (i.e. the City of Medicine Hat). ${ }^{79}$ As this example highlights, actor types can be different depending on the point in the social innovation process that one is considering. 
Actor types are relevant to social innovation because they alter the tools available to groups promoting a socially creative strategy. This has an effect on the social innovation process inasmuch as it alters the sources of power possessed by the actor type in question. That is, a government agency possesses a different set of tools than a social movement or non-governmental organization; this may shape how different aspects of social innovation are undertaken. For example, two separate attempts to establish supervised injection facilities in British Columbia experienced very different challenges due to the actor types involved. In 1994, a group of users and advocates established the 'Back Alley Site', a supervised injection facilities that was closed down by police that same year. ${ }^{80}$ When Insite was set up, in contrast, it obtained a 3-year exemption under s.56 of the Controlled Drugs and Substances Act, which allowed it to operate legally. ${ }^{81}$ Municipal government support was critical to achieving this exemption.

\section{Sequencing}

While the framework above has identified core requirements of the social innovation as it moves toward an end state, the process of social innovation may not be linear. ${ }^{82}$ For example, problem identification may occur before or after a socially creative strategy has been identified; while this may seem counter-intuitive, the prevalence of transmitting socially creative strategies from one context to another renders it possible. Illustrative in this regard is the ongoing debate about supervised injection facilities in Canada. Although Insite drew upon similar programs in Western Europe, the central challenge that this socially creative strategy has encountered is in defining the problem of illicit 
Innovation Policy Lab White Paper 2016-01

drug use. While all actors identify the problem of illicit drug use, actors disagree on whether to define the problem as a public health issue, as compared with one of law enforcement. At the municipal and provincial levels, the harm reduction approach preceded the socially creative strategy. However, the federal government continues to define the problem of illicit drug use as a criminal issue, resulting in institutional pushback that has encumbered the program's expansion. ${ }^{83}$

\section{Nature of Socially Creative Strategy}

The requirements of the socially creative strategy may differ along two main dimensions: the target community and the type of socially creative strategy.

First, the challenges of spreading a norm will vary depending on whether the target community is narrow or wide, diffuse or clearly defined. The scope of the target community will influence the manner by which mobilization is best achieved, for example. As an illustration of this point, consider designated driving, as compared with FoodCloud. The socially creative strategy of designated driving sought to establish widespread practice encompassing all who might drink and drive. This is a large and diffuse community. As such, to spread this norm a narrower intermediary community was mobilized: establishments serving alcohol (in Canada) and mass communications platforms (in the U.S.). ${ }^{84}$ In comparison, FoodCloud - an organization funded by Social Entrepreneurs Ireland that connects businesses with local charities in order to simultaneously reduce food waste and malnutrition. The two target communities here businesses in Ireland with surplus food and local charities that distribute food as part of 
their service mandates - are narrow and defined, allowing FoodCloud to directly mobilize both by connecting them to one another through a web application. ${ }^{85}$ Second, a socially creative strategy will face different needs as it proceeds through emergence and adoption depending on the needs of the intervention type. More specifically, we might consider whether it is, say, a service to be delivered as compared with a norm change. We might expect that the social innovation diffusion cycle will differ according to the type of socially creative strategy. Three examples illustrate potentially relevant differences herein. While the involvement of authorities is important to norm change, including in the case of designated driving (for example through a permissive legal environment, the support of liquor serving establishments, and the use of mass communications platforms to spread awareness), successful norm change chiefly requires that the broader public agree with the practice and undertake to follow it. In contrast, the housing first approach to tackling homelessness largely requires the institutionalization of this strategy through resource allocation (although effective demand by the target population is also necessary). As a third example, the Forest Stewardship Council eco-label demonstrates how norm change and targeted interventions may simultaneously be necessary to the success of a socially creative strategy. While a few industry leaders may drive initial eco-label uptake, to be adopted across the industry and thus have an effect, consumers must demand eco-labels in their purchasing habits.

\section{E. The Policy Goals Served by Social Innovation}


Above, we have defined social innovation and outlined a framework for combining the different existing strands of research studying how it unfolds, cognizant that the institutional context matters. However, social innovation has also been viewed as a policy imperative - something that governments, foundations, charities, and businesses should encourage and support. We posit that there are three goals served by nurturing social innovation, each of which implies different policy stances: to find effective new solutions to social problems; to replicate and/or scale-up existing solutions; and to connect communities and empower individuals.

\section{Efficacy in Responding to a Social Problem}

First, social innovation may be sought for the purpose of finding an effective response to a problem, whether through redefining social needs or responding to a social need as already defined by the actor in question. Social innovation conveys the need for experimentation and tolerance within institutions for risk taking and failure. ${ }^{86}$ Through its study, we are able to better understand how to nurture creativity and approach the uptake of ideas within the public and voluntary sectors.

If this objective is reached, a socially creative strategy will address a "previously unmet" social need or will find a more "efficient" or "effective" way to meet a social need. ${ }^{87}$ This goal of social innovation is sometimes critiqued for its association with neoliberalism in public services - due, in part, to the term's connection with post-2008 austerity in Europe and the prevalence of "efficiency" in social innovation discourse $-{ }^{88}$ but the validity of this appraisal largely depends on who is using the term and toward what purposes. 
Notably, it has been argued that social innovation is a tool to support human development, associated with a reinvigoration, rather than a withdrawal, of the welfare state. $^{89}$

\section{Sustainability and Empowerment}

Second, through the mobilization that occurs in emergence and adoption, social innovation may result in the empowerment of given communities, generating sustainable social action. ${ }^{90}$ In this sense, social innovation ideally produces a lasting change in social practices such that it reshapes society "in the direction of participation and empowerment". ${ }^{91}$ The objective, then, is to encourage social innovation as a way to empower individuals and groups to identify social needs and act collectively to meet them, thereby expanding their influence and challenging other social spaces. ${ }^{92}$ This goal of social innovation is simultaneously individual, targeted at expanding substantive freedoms, ${ }^{93}$ and collective, aimed at achieving greater social sustainability. ${ }^{94}$

\section{Scaling and Replication}

A final policy goal of social innovation is to replicate or scale-up successful initiatives. ${ }^{95}$ In this sense, social innovation parallels economic works on start-ups and the best way to bring new ideas to scale. ${ }^{96}$ However, the 'social economy'97 (the public sphere and civil society; government, charities, and non-profits) does not comprise the same institutions as the market. In this sense, one challenge is to provide effective demand for socially creative strategies by identifying the best way to arrange institutions such that 'good' 
ideas can be replicated or scaled up, while weeding out the bad ones. ${ }^{98}$ Another is to ensure that socially creative strategies have the capacity to grow. ${ }^{99}$ This can be done by studying the social innovation process - in which new ideas emerge and are adopted across a social space.

\section{CORE ASPECTS OF OUR APPROACH}

The framework above aims to present social innovation as a meta-disciplinary concept that can bring together diverse research communities in a coherent way. In doing so, we have made several potentially controversial choices. Below we present justifications for three aspects of our conceptual framework which are new or controversial in the literature: defining social innovation as a process; stating that a social innovation need not deliver social benefit; and identifying dual engines that drive social innovation.

\section{A. Social Innovation is a Process}

In the framework presented above we opted to define social innovation as a process. This requires justification, as social innovation has been defined as a process, an outcome, and as both a process and an outcome. ${ }^{100}$ Notably, an attempted consensus definition has emerged which presents social innovation as both a process and an outcome. Although our process definition of social innovation diverges from the emerging consensus definition of social innovation, we believe that this is desirable for three reasons. 
First, while an attempt has been made to create a consensus definition of social innovation (and this definition has been used or adapted with small modifications by multiple authors), we do not agree that this definition is a sound basis upon which to base social innovation research. Moulaert and colleagues, in their influential book, The International Handbook on Social Innovation, define social innovation as "innovation in social relations", referring to particular actions as well as "the mobilization-participation processes and to the outcome of actions which lead to improvements", whether improvements are defined as empowerment or improvements in addressing a social need. ${ }^{101}$ Unfortunately, this definition reflects an accommodative amalgam of different approaches, rather than genuine convergence on the meaning of the term.

This is a problem for two reasons. First, defining social innovation in terms of the presence or absence of "changes in social relations", the Moulaert and colleagues definition provides no basis upon which to assess differences in social change or to theorize social innovation as one way in which change comes about. While we agree with the purpose behind including this characteristic - one of the key analytical gains of social innovation is its ability to help us to understand social change - it is inadequate to define social innovation, tautologically, as a change in social relations. Second, the accommodative stance is an obstacle to practical study of social innovation because defining social innovation as both an outcome and a process obstructs from the ability to disentangle what actually is meant by the term. To our minds, there is no advantage to using the same term to describe two distinct concepts. While social innovation does create outcomes, and we understand the impulse to include them within a definition so as 
to indicate causality between the process and the outcome, it is confusing to present social innovation as a homograph for these two distinct concepts.

Social innovation, if it is to be a coherent concept with a specific meaning, cannot be simultaneously a process and an outcome. As such, we have defined social innovation as a process encompassing a set of actions that lead to outcomes. By doing this, we have made it possible to identify concepts that are a part of this process such that social innovation can be demystified and instead treated as an object of study. Specifically, we suggest that the process of social innovation includes actors as they interact in their social environment; involves the development of a socially creative strategy; and has an end state, which produces related outcomes.

Next, a process definition provides the foundation upon which to present social innovation as a 'meta-disciplinary framework' and, thereby, bring together research on social change from across disciplinary boundaries. ${ }^{102}$ Unfortunately, in absence of a unifying conceptual framework social innovation research has been unable to reach this potential. Instead, as can be seen in Appendix 1, which presents our modularity analysis, we observe that social innovation research is fragmented into five largely self-contained groupings. Accordingly, we propose that a process definition of social innovation is a necessary first step for establishing a framework that can bring together work on social innovation from across research programs. We illustrated this point by showing how different concepts that are already used in the social innovation literature (i.e. the social entrepreneur, social capital, motivation, the social environment, and empowerment) fit within our conceptualization of the social innovation process. This is important because it 
allows for more fruitful cross-disciplinary academic discussion, providing a way to account for the interaction between agency and structure in social change. Further, doing so is also critical from a policy perspective, as it provides the starting ground for a more theoretically coherent version of the 'stages of social innovation' matrices that practitioners have presented (more on that below). ${ }^{103}$

Third, by separating social innovation from socially creative strategies as a conceptual matter, we aim to reduce confusion about what is to be studied, allowing for greater precision in our understanding of what social innovation is, how it comes about, and how it can be encouraged from a policy point of view.

\section{B. Social Innovation Need Not Deliver a Social Benefit}

Our definition requires that a socially creative strategy aims to meet a social goal, but not that it actually meets this goal or otherwise 'improves' society. This contrasts with much of the literature, for which the delivery of a social benefit is a defining feature of social innovation. ${ }^{104}$ This is sometimes described as the 'outcomes' approach to social innovation. For example, social benefit features prominently in the Open Handbook of Social Innovation definition of social innovation: "[s]ocial innovations are new solutions (products, services, models, markets, processes etc.) that simultaneously meet a social need (more effectively than existing solutions) and lead to new or improved capabilities and relationships and better use of assets and resources." 105 In another case, social innovation is defined as “innovations that are both good for society and enhance society's capacity to act." ${ }^{\text {"106 }}$ While in most cases authors do not specify what a 'social good' might 
entail, there have been attempts to generate an objective and measurable standard. ${ }^{107}$ One such example defines social benefit as an improvement in "either the quality or the quantity of life." 108

We diverge from this approach: while our definition requires that a socially creative strategy is aimed at meeting a social goal, we allow for the possibility that this goal may not be met and that society may not 'benefit' overall, for example if the side effects of the intervention produce harm. We do so for several reasons.

First, the outcomes approach to social innovation meets difficulties in arriving at an agreed standard by which to identify whether social innovation has occurred. Although, as noted above, attempts have been made to select objective measures such as quality of life, it is unlikely that such measures can capture the full array of social innovation activities that are ongoing. This is because identifying the delivery of social benefit inevitably rests on a normative conception of what is 'good' for society. This poses barriers to arriving at an externally agreed upon standard for defining when social innovation has occurred, which in turn prevents opening up the concept to objective inquiry.

Moreover, because social innovation has come to connote 'good' outcomes, it is increasingly deployed as a normative-productive (rather than descriptive) term. ${ }^{109}$ As is shown in Appendix 2, social innovation is commonly used for strategic purposes, resulting in its widespread use in business corporate social responsibility communications ${ }^{110}$ as well as by governments, intergovernmental organizations and civil society groups. ${ }^{111}$ While we should expect social innovation to be used strategically, this 
becomes a problem when its normative element is so closely tied to the meaning of the concept.

There are some who claim that the concept of social innovation is inescapably normative. ${ }^{112}$ While we acknowledge that the researcher is never separated completely from his subject inasmuch as is true for all social science, ${ }^{113}$ we see no reason that would preclude one from striving for social scientific standards in the study of social innovation. The solution, to our minds, is to eliminate the requirement that social innovation deliver a social benefit. This requirement serves no analytical purpose. Moreover, shedding it enables the literature to study social innovation where the outcome may be controversial or even nefarious. ${ }^{114} \mathrm{We}$ contend that the same process of social innovation holds whether those studying it agree with the identified social goal of a socially creative strategy or not. If this supposition holds true, we should study social innovation regardless of whether 'social benefit' is delivered, instead treating the identification of a social goal as an object of inquiry. Our approach accords with those works on social innovation that conceptualize social purpose as a motivation driving socially creative strategies. For example, social innovation has been described as "the attempt to instrumentalize social relationships to formulate and implement strategies that tackle societal problems." ${ }^{\prime 15}$ From this view, it is the intended effect that matters, rather than the actual result. ${ }^{116}$

C. Social Innovation is Driven by the Interaction of Agents and Social Structure, Not an Evolutionary Logic of Competition 
In explaining why the agentic and structural engines are an important contribution to the social innovation literature, it is first important to provide some context. Scholarship on social innovation is divided on whether the process of social innovation can be studied by drawing upon innovation theory (the mono-innovation claim) ${ }^{117}$ or should be considered as an entirely separate area of inquiry.

The study of innovation in economics, beginning from Schumpeter's seminal text, ${ }^{118}$ is buttressed by the supposition that the capitalist system of competition induces innovation, which is a key driving force of growth. Innovation scholars have identified the capitalist system itself as the 'engine' of innovation: the structure of the market system drives decisions by its actors (firms), which lead to innovation. ${ }^{119}$ This view is underpinned by an 'evolutionary' logic of economics driven by competition. Some social innovation scholars - those adhering to the mono-innovation claim - have sought to widen existing theory on market innovation to incorporate its social aspects. ${ }^{120}$ Here, the 'social' element of social innovation refers to the social nature of the processes to which such innovation is directed or through which innovation of a non-social kind is translated from idea to practice. ${ }^{121}$ From this view, the nature of the innovation process itself does not change; social innovation is simply innovation that "is induced by some kind of social need and/or is aimed at solving a critical social problem." ${ }^{122}$ This view implies that social innovation theory can largely draw upon existing innovation theory for its conjectural architecture. Given its association with market innovation, this concept is most often evoked in works on social innovation stemming from business and management. ${ }^{123}$ 
A second approach contests the mono-innovation claim, instead arguing that social innovation requires an entirely separate theoretical framework. Typifying this approach are those that study social innovation as resilience or social transformation. Such authors emphasize that the 'social' nature of the outcome is such that the processes, metrics, models and methods used in innovation in the market are not always transferrable outside of it. ${ }^{124}$ A stronger iteration of this approach emphasizes the different logics at play in 'evolutionary' economic systems, as compared with social ecosystems that rely on institutional adoption for the production and reproduction of new practices. ${ }^{125}$ We align ourselves with this second approach, as it is our view that social innovation follows logics and mechanisms that are distinct from market innovation, due to the system within which it is situated. In particular, the logic associating innovation with advancement is tied to evolutionary postulates about market-based competition: good innovations survive the test of competition, while bad innovations do not. To the extent that this evolutionary logic holds for market innovations, it is unclear that that this is an applicable lens of analysis in social systems.

At its most extreme, this might prompt one to question whether the concept of innovation is useful in the social sphere: is anything gained by using the term social innovation that one could not access through existing analytical tools - such as critical juncture theory and theories of norm entrepreneurship and the norm life cycle? ${ }^{126}$ In our view, yes: we agree with Jessop and colleagues that social innovation can usefully serve as a metadisciplinary framework for understanding how change in the patterns of social relations occurs. ${ }^{127}$ Moreover, as a policy imperative greater understanding of such processes can 
help governments and actors within the social economy to strategically channel efforts in accordance with the logic of social innovation, such that they can best work to realize their goals. However, this requires that social innovation be theorized not according to the logic of market systems (by borrowing from innovation theory) but, instead, via a separate theory of social innovation that is 'social' at its core. As such, a theory of social innovation must identify the forces underlying social innovation as a cause of social change.

Accordingly, we have attempted to design a truly social conceptual framework for social innovation by basing it on the driving forces of social life: the interaction of structure and agency. ${ }^{128}$ Framing social innovation as a process occurring through dual engines, one structural and one agentic, allows us to account for the dialectic that is embodied in social action. Stated more simply, individuals can act to change how society responds to a problem; as he acts, however, he will be constrained by his social environment. Whether a socially creative strategy is able to emerge and is adopted across society depends on individual actions as well as existing rules, social groupings, and so on. By setting up these dual engines as the centrepiece of our theory on social innovation, we ensure that studies deploy a social, not evolutionary or economic, logic of change.

\section{ADVANTAGES OF OUR FRAMEWORK}

Above, we have introduced a framework that will advance the study and practice of social innovation. In this section, we discuss the benefits of our approach for scholars and practitioners. 


\section{A. For Scholars}

Our framework has the potential to advance scholarly work on social innovation, as it provides the basis for cross-disciplinary study and begins from a theory that is social at its foundation.

First, as described above, our framework can bring together research from across research communities such that social innovation can become, as some scholars have advocated, a meta-disciplinary framework. ${ }^{129}$ Given the fragmentation of the literature (discussed above), our framework has been designed to incorporate concepts from the five different social innovation research communities in a coherent manner. We described the process of social innovation as consisting of the interaction between two mechanisms, which lead to two outcomes. Within these macroscopic logics of social innovation, we described nine central concepts (social entrepreneur, socially creative strategy, social problem, emergence, adoption, social environment, social structures, social goal, and social change) and the relations amongst them. It is from this starting point, we believe, that the five social innovation research communities - psychology of creativity, psychology and innovation, social entrepreneurship, innovation studies, and territorial and urban development (described below in Appendix 1) - can bring their research to a unified area of study on social innovation. ${ }^{130}$ For example, the social innovation research communities on the psychology of creativity and psychology and innovation can help to explain the link between a social entrepreneur, the social problem, and the socially creative strategy. Studies on social entrepreneurship speak to this as well, and may 
further provide insight on how socially creative strategies proceed through the emergence phase. Studies of territorial innovation and urban development, which are concerned with social transformation, can contribute through concepts, such as institutionalization, that describe how the structural engine of social innovation shapes the process throughout. This literature may help to improve upon existing 'stages' graphics on social innovation by adding structural variables. ${ }^{131}$ After all, as we emphasized, the institutional context is critical to arriving at a greater understanding of different processes of social innovation. Three variables are, we posit, central to distinguishing different routes of social innovation.

Next, our framework provides the foundation for a social theory of social innovation. As we argued above, there is good reason to believe that social innovation proceeds according to an altogether different logic than market innovation, which is theorized in evolutionary terms. We believe that in practice there has generally been an acknowledgement that social innovation requires a theoretical framework that is different from theories of market innovation. However, this acknowledgement has failed to percolate as deeply as is necessary for a coherent theory of social innovation. For example, a 'life cycle of social innovation' has been devised which traces the occurrence of social innovation from the conception of an idea through to the growth or failure of the idea and the spread of its structures and impact. ${ }^{132}$ While this framework is superficially distinct from works on market innovation, its underlying logic, an analogy to evolutionary theory, remains economic in orientation. Our framework, in contrast, is unabashedly social, beginning from the interaction of two driving forces of social life 
(structure and agency).

\section{B. For Practitioners}

This framework can be usefully applied to advance thinking on how authorities can recognize and encourage social innovation. This is true, first, because it enables the study and practice of social innovation to draw from a single framework. Second, our framework presents a more accurate conception of how social innovation unfolds in practice.

One key aim of this paper is to strengthen the link between academic study and practice by establishing a framework that can be relevant to each. We believe that this is a necessary first step for creating social innovation policy that advances its identified objectives - which, as described above, include efficacy, empowerment, and scalability. While practitioners of social innovation have offered tangible policy recommendations, there is often no theoretical coherence tying such policy suggestions together. ${ }^{133}$ The result has been the proliferation of laundry lists, with little examination of the mechanisms underlying social innovation. ${ }^{134}$ This limits policy efficacy because absent a robust theoretical framework one is precluded from understanding how interactions, trade-offs, and externalities might affect best practice on social innovation.

It would be inaccurate to place the blame for this phenomenon on practitioners, however. Unfortunately, academia has remained too far removed from practice in its treatment of social innovation, as discussed above. This deficiency limits policy applicability, the result of which is that strong scholarly work on social innovation is not used by 
practitioners. Our framework is aimed at rectifying this problem by creating the basis upon which practitioners can read academic works on social innovation and know how they might relate to policy on social innovation. It is the starting point for a blueprint of social innovation that can be used, by practitioners and academics, to draw lessons from specific case studies. For example, a case study on how a logging blockade altered the routines, authority flows, and beliefs of the social system in British Columbia might generate useful lessons on how socially creative strategies can alter social structures, how social innovation produces the outcome of social change, and how social innovation serves the objective of empowerment. ${ }^{135}$

Second, the framework developed in this paper is preferable to the presentations of social innovation stages or lifecycles, which usually base their concepts on product development. For example, in the influential publication The Open Book of Social Innovation, Murray, Caulier-Grice and Mulgan advance six stages of social innovation and discuss the supports that might help a social venture to engage in each. ${ }^{136}$ While we applaud the breadth of analysis undertaken by the authors, this approach unfortunately assumes that all social innovation emanates from a social venture, operating in a manner similar to a start-up company. This may certainly be helpful for some instances of social innovation but misses much of the socially creative strategies that exist. First, as the examples above illustrate, it is often not the case that a single social entrepreneur resolutely promotes the socially creative strategy throughout the social innovation process. We posit that a more common model of social innovation includes different actor types exhibiting greater levels of leadership at different points in the process. 
Moreover, the stages framework misses entirely analysis of institutional resistance, which, as the case of the supervised injection facility Insite exemplifies, may play a critical role in encumbering a socially creative strategy. Actors that wish to promote social innovation need a framework that provides a way of thinking about such factors. Finally, only our framework can help practitioners that seek to fund socially creative strategies that target norm change. Our framework is an improvement, then, because it arranges thinking on social innovation in a way that is more relevant to how social innovation actually unfolds.

This is true, moreover, in regards to the economic logic that underlies existing models of social innovation (discussed above). Although most practitioners, quite appropriately, do not feel it necessary to resolve the agent-structure problem before beginning their work, we argue that in the case of social innovation it is important that policy-makers, not just academics, draw upon a model of social innovation that deploys a social logic. There are policy implications to the claim that the evolutionary logic of market innovation does not apply to social innovation. For one thing, an evolutionary logic of competition will predict that different socially creative strategies will be successful. As such, for practitioners hoping to fund socially creative strategies in order to maximize a social impact it is important to draw granting criteria from accurate suppositions about how social innovation occurs and what obstacles might prevent socially creative strategies from being successful. The better socially creative strategy in abstract terms might not be the one that succeeds, as socially creative strategies may fail due to institutional resistance, difficulties in reaching a target community, or any number of other 
Innovation Policy Lab White Paper 2016-01

institutional factors. As such, our framework provides a better basis for evaluating the worthiness of socially creative strategies. 
Innovation Policy Lab White Paper 2016-01

\section{APPENDIX 1: MODULARITY ANALYSIS OF THE SCHOLARLY SOCIAL INNOVATION LITERATURE}

A Web of Science (WoS) search was conducted on 11 May 2015 for all material on the topic of "social innovation" for the years 1900 to $2015 .{ }^{137}$ The search returned 396 results. Additionally, to allow for a more complete analysis of the field, citation data was included. This encompassed cross-citation occurring between publications returned by the topic search as well as external citations (publications cited by publications returned by the search). The data also included publication "research areas". ${ }^{138}$ Once extracted, the data was analyzed using the visualization and analysis tool Gephi. ${ }^{139}$ Gephi was also used as a platform to conduct a modularity analysis. ${ }^{140}$ From this analysis, several findings emerged:

i. No single disciplinary approach dominates the SI literature, although business economics contributed a clear plurality of results.

Analysis of this data shows that business economics has clearly contributed the most works to the SI literature, with 117 publications (29 percent of returned publications). However, several other disciplines were also found to publish on SI. Environmental sciences ecology; psychology; public administration; and engineering each all contributed between 9 and 13 percent of total return publications.

ii. Five distinct communities of research exist in the SI literature and are characterised by a high degree of inter-citation by a small number of authors. 
Next, the modularity analysis of citation patterns grouped the larger citation network into smaller communities, organized by the degree of connectedness. ${ }^{141}$ The analysis revealed five distinct research communities. ${ }^{142}$ These research communities are characterized by a high degree of inter-citation by a small number of authors. ${ }^{143}$ The table below summarizes distinctions between the five research communities in terms of publication type, general topic, geography, and prominent authors.

\section{Table: SI Research Communities}

Research Community

\begin{tabular}{|l|l|l|l|l|l|}
\cline { 2 - 6 } & A (purple) & B (green) & C (yellow) & D (blue) & E* \\
\cline { 2 - 6 } Issue Area & $\begin{array}{l}\text { Psychology of } \\
\text { Creativity }\end{array}$ & $\begin{array}{l}\text { Territorial } \\
\text { Innovation } \\
\text { and Urban } \\
\text { Development }\end{array}$ & $\begin{array}{l}\text { Social } \\
\text { Entrepreneurship }\end{array}$ & $\begin{array}{l}\text { Innovation } \\
\text { Studies }\end{array}$ & $\begin{array}{l}\text { Psychology and } \\
\text { Innovation }\end{array}$ \\
\cline { 2 - 6 } $\begin{array}{l}\text { Affiliation } \\
\text { 144 }\end{array}$ & North America & $\begin{array}{l}\text { Belgium, } \\
\text { UK, Europe }\end{array}$ & United Kingdom & $\begin{array}{l}\text { North } \\
\text { America }\end{array}$ & United States \\
\cline { 2 - 6 } Top Authors & Mumford, \\
Marcy, Weick & $\begin{array}{l}\text { Moulaert, } \\
\text { Swyngedouw }\end{array}$ & $\begin{array}{l}\text { Mulgan, } \\
\text { Alvord, Geels, } \\
\text { Seyfang }\end{array}$ & $\begin{array}{l}\text { Patton et } \\
\text { al., Von } \\
\text { Hippel, } \\
\text { Gunderson }\end{array}$ & Fairweather \\
\cline { 2 - 6 }
\end{tabular}

iii. The SI literature is fragmented, as the five research communities emanate from distinct disciplinary traditions and are only loosely connected by citations.

Analysis of the modular communities confirms that the term 'social innovation' is being applied in different disciplines and contexts, with little exchange of ideas across these intellectual clusters. Connections between the research communities are manifested 
generally through common citation of much older publications ${ }^{145}$ or citation across communities of articles by a research community leader. ${ }^{146}$

Community A, the most prolific research community, focuses its discussion around the psychology of creativity, and operates largely within the United States and Canada.

Community B, however, focuses on territorial innovation and urban development, and operates largely in Europe. Community $\mathrm{C}$ is the most geographically diverse, primarily including authors from the United Kingdom and the eastern United States, and focuses on social entrepreneurship. Community D is more focused on business innovation and is strongly linked to Community E, which is focused on the psychology of innovation. Despite these divisions in the SI literature, the most highly cited publications are evenly distributed amongst the modular communities.

iv. Some highly cited articles were not strongly tied to any of the dominant research communities.

Some highly cited articles were not grouped by the modularity analysis (shown in the section labeled 'other'). This is because they were not strongly tied to any of the dominant communities.

\section{$\underline{\text { Table: Most Cited Articles }}$}

\begin{tabular}{|c|c|}
\hline Label & Citation Count \\
\hline Research Community A & \\
\hline $\begin{array}{l}\text { Mumford, M. D. (2002). Social innovation: Ten Cases from Benjamin } \\
\text { Franklin.Creativity Research Journal, 14(2), 253-266. }\end{array}$ & 25 \\
\hline
\end{tabular}




\begin{tabular}{|c|c|}
\hline $\begin{array}{l}\text { Marcy, R. T., \& Mumford, M. D. (2007). Social innovation: Enhancing } \\
\text { Creative Performance Through Causal Analysis. Creativity Research } \\
\text { Journal, 19(2-3), 123-140. }\end{array}$ & 12 \\
\hline Mumford, M. D. (2003). Where Have We Been, Where Are We Going? & 12 \\
\hline $\begin{array}{l}\text { Taking Stock in Creativity Research. Creativity Research Journal, } \\
15(23), 107-120 .\end{array}$ & \\
\hline \multicolumn{2}{|l|}{ Research Community B } \\
\hline $\begin{array}{l}\text { Moulaert, F., Martinelli, F., Swyngedouw, E., \& Gonzalez, S. (2005). } \\
\text { Towards Alternative Model(s) of Local Innovation. Urban studies, } \\
\text { 42(11), 1969-1990. }\end{array}$ & 18 \\
\hline $\begin{array}{l}\text { Swyngedouw, E. (2005). Governance Innovation and the Citizen: the } \\
\text { Janus Face of Governance-Beyond-the-State. Urban Studies, 42(11), } \\
\text { 1991-2006. }\end{array}$ & 11 \\
\hline \multicolumn{2}{|l|}{ Research Community C } \\
\hline $\begin{array}{l}\text { Mulgan, G., Tucker, S., Ali, R., \& Sanders, B. (2007). Social innovation: } \\
\text { What It Is, Why It Matters and How It Can Be Accelerated. }\end{array}$ & 31 \\
\hline $\begin{array}{l}\text { Mulgan, G. (2006). The process of social innovation. innovations, l(2), } \\
\text { 145-162. }\end{array}$ & 12 \\
\hline $\begin{array}{l}\text { Alvord, S. H., Brown, L. D., \& Letts, C. W. (2004). Social } \\
\text { Entrepreneurship and Societal Transformation: An Exploratory } \\
\text { Study. The Journal of Applied Behavioral Science, 40(3), 260-282. }\end{array}$ & 11 \\
\hline \multicolumn{2}{|l|}{ Research Community D } \\
\hline $\begin{array}{l}\text { Westley, F., Zimmerman, B., \& Patton, M. (2009). Getting To Maybe: } \\
\text { How the World is Changed. Vintage Canada. }\end{array}$ & 14 \\
\hline \multicolumn{2}{|l|}{ Research Community E } \\
\hline Fairweather, G. W. (1967). Methods for Experimental Social Innovation. & 12 \\
\hline \multicolumn{2}{|l|}{ Other } \\
\hline $\begin{array}{l}\text { Moulaert, F., Martinelli, F., González, S., \& Swyngedouw, E. (2007). } \\
\text { Introduction: Social Innovation and Governance in European Cities: } \\
\text { Urban Development Between Path Dependency and Radical } \\
\text { Innovation. European Urban and Regional Studies, 14(3), 195-209. }\end{array}$ & 16 \\
\hline $\begin{array}{l}\text { Phills, J. A., Deiglmeier, K., \& Miller, D. T. (2008). Rediscovering } \\
\text { Social Innovation. Stanford Social Innovation Review, 6(4), 34-43. }\end{array}$ & 16 \\
\hline $\begin{array}{l}\text { Murray, R., Caulier-Grice, J., \& Mulgan, G. (2010). The Open Book of } \\
\text { Social Innovation. National Endowment for Science, Technology and } \\
\text { the Arts. }\end{array}$ & 14 \\
\hline $\begin{array}{l}\text { Chesbrough, H. W. (2006). The Era of Open Innovation. Managing } \\
\text { Innovation and Change, 127(3), 34-41. }\end{array}$ & 12 \\
\hline
\end{tabular}




\section{APPENDIX 2: SOCIAL INNOVATION IN PUBLIC DISCOURSE}

To capture the use of social innovation in public discourse, we undertook a Factiva ${ }^{147}$

search of the term "social innovation" 148 across all available publications for the last five years. Our search yielded 21511 texts that referred to social innovation. A significant limitation of this search is the inclusion of only the English and French terms for social innovation, eliminating many references to the term and skewing regional patterns. Unsurprisingly, main states represented in the search were English and French-speaking countries, although Japan and other European Union countries ranked highly as well. Nonetheless, the search suggests several general trends.

i. Use of SI has grown in the last five years.

The number of texts deploying the term "social innovation" has increased steadily between 2010 through to the end of 2014 , as is shown in the chart below. ${ }^{149}$ 


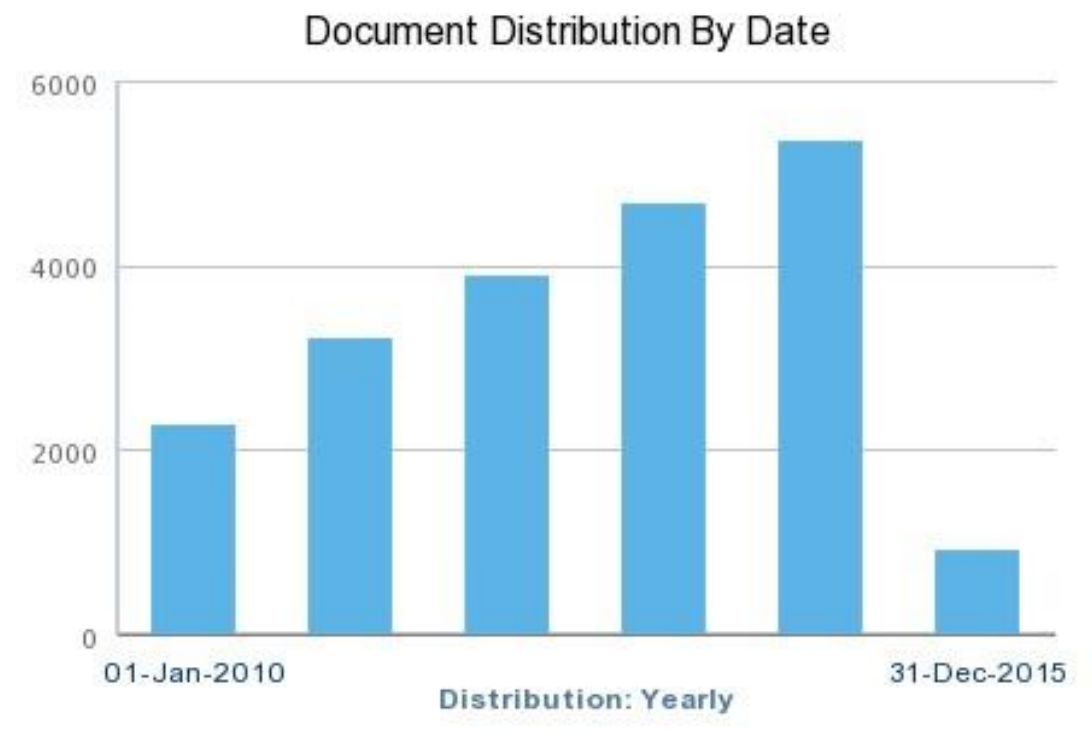

$20.2 \mathrm{~K}$ documents In the last 5 years

\section{ii. Business is an important source of SI discourse.}

Next, business is an important source of social innovation discourse, perhaps eclipsing its use in reference to government policy and state-society relations. Evidence of this dynamic was borne out in several search categories, but includes the ten most often mentioned individuals in the documents under study. Of the ten individuals most often mentioned in the texts, all but two were business executives or press contacts (the two non-business mentions were for President Barack Obama and Ontario Premier Kathleen Wynne). Further available evidence of this point relates to document key words. The top keywords associated with this search, in addition to the terms themselves, included: Ansaldo STS, ${ }^{150}$ social enterprises, New York, San Francisco, research laboratory, social enterprise, innovation business, and Hitachi Rail. ${ }^{151}$ Press releases, which accounted for 3877 documents, mainly pertained to the use of social innovation by business. When 
press releases are excluded from the search terms, the business keywords are replaced with terms suggesting a political, EU-oriented, emphasis: états membres, entreprises sociales, social entrepreneurship, union européene, and politique sociale. This finding points possibly to the prominence of social innovation as a corporate social practice, as well as collaborations involving business actors.

iii. Few of the texts returned in the search were from civil society groups.

Third, the civil society sector was underrepresented, in comparison to business and government and perhaps in contrast to common sense expectations given the theoretical orientations of the term. While philanthropic foundations, non-profit organizations, and charities did feature in the texts, of course, they were eclipsed by mention of government and corporate actors. In part, this may reflect the diffuse set of actors at play in NGO communities. However, this explanation cannot capture the entire phenomenon given that the same logic might be applied to companies: there are several large global NGOs that might have been expected to be included in many social innovation publications. As well, both the global civil society and business communities include diffuse sets of actors. This may suggest a need to reconcile current academic work with the evolving commonsense meaning of the term, or at the very least to be cognizant of the volitions and trends animating the term's usage in common parlance.

iv. The European Union is well represented in SI discourse. 
Fourth, the European Union, unsurprisingly, was a key theme in the social innovation

discourse. In this regard, it is worth noting the top organizations associated with the term social innovation. Of the top ten most mentioned organizations, six were bodies of the European Union; three were companies; and the final source was the U.S. Corporation for National and Community Service, which operates that country's social innovation fund.

v. The US is a prominent source of SI discourse.

Finally, the findings suggest that the United States remains prominent source of social innovation. In addition to being the top source of search yields overall, the key word search included two U.S. cities - New York and San Francisco.

\section{ENDNOTES}

\footnotetext{
${ }^{1}$ Mumford, M.D. (2002). Social Innovation: Ten Cases from Benjamin Franklin. Creativity Research Journal 14(2), 253-266; Moulaert, F., MacCallum, D. \& Hillier, J. (2013). Social Innovation: Intuition, Precept, Concept, Theory and Practice. In Moulaert et al. (eds.) The International Handbook on Social Innovation: Collective Action, Social Learning and Transdisciplinary Research. Northampton, MA: Edward Elgar.

${ }^{2}$ Tansey, J. (2011). A Social Innovation Primer. Sauder School of Business; Păunescu, Carmen. (2014). Current Trends in Social Innovation Research: Social Capital, Corporate Social Responsibility, Impact Measurement. Management and Marketing. Challenges for the Knowledge Society 9(2) 105-118.

${ }^{3}$ Boggs Davidsen, Elizabeth. (2 July 2015). Corporate Social Innovation is the New Corporate Social Responsibility. Huffington Post Business Blog, at http://www.huffingtonpost.com/fomin/corporatesocialinnovati_b_7714714.html; Strandberg, Coro. (18 November 2015). Corporate Social Innovation: a New Business Value Driver. Social Innovation Generation (SiG), at http://www.sigeneration.ca/corporatesocialinnovation-new-business-value-driver/\#.VkyfTB5177c.twitter.

${ }^{4}$ See http://redinnovation.org/.

${ }^{5}$ See, for example, McGath, Thomas. (30 March 2015). Alternative Economy: the Rise of Social Innovation in Berlin. The Guardian; Haworth, Matt. (11 March 2015). Why the Apple Watch Offers Smart
} 
Opportunities for Social Good. The Guardian; Zavadszky, Andrea. (9 March 2015). Strategizing for Living Designs. South China Morning Post; Hunter, Justine. (3 January 2015). Innovation Comes in Many Forms with Endless Benefits. The Globe and Mail; Grant, Kelly. (7 June 2014). Tower Troubles. The Globe and Mail; (30 May 2014). Creativity and Innovation Thrive on Energy Sector's Fertile Ground. The Globe and Mail.

${ }^{6}$ For example, the Open Book of Social Innovation lists 527 ways to support social innovation, with no comparative analysis of these strategies. See Murray, R., Caulier-Grice, J. \& Mulgan, G. (2010). The Open Book of Social Innovation. The Young Foundation and NESTA, at http://youngfoundation.org/wpcontent/uploads/2012/10/The-Open-Book-of-Social-Innovationg.pdf.

${ }^{7}$ See modularity analysis at Appendix 1.

${ }^{8}$ Pol E. \& Ville, S. (2009). Social Innovation: Buzz Word or Enduring Term? The Journal of SocioEconomics 38, 878.

${ }^{9}$ For example, this is the approach taken by several chapters in Moulaert et al. supra note 1.

10 The concept of a process was brought into social science from biology. A biological process is "based on two main principles: first, the existence of different entities, and second, the interaction between these entities." A social process, then, is an observable pattern of social interactions that has a consistent direction. See Bardis, Panos D. (1979). Social Interaction and Social Processes. Social Science 54(3) 147167 at 148. A social process has also been defined as "a set of connected events occurring according to specifiable rules and within specifiable parameters of time". While Vayda et al. are concerned that use of the term process by social scientists often has resulted in a systems oriented view which reifies structure over agency. As we include the mutual constitution of structure and agency as dual engines of the process of SI, our use of SI as a process does not suffer from this deficiency. See Vayda, Andrew, McCay, Bonnie, and Eghenter, Cristina. (1991). Concepts of Process in Social Science Explanations. Philosophy of the Social Sciences 21(3) 318-331 at 319. While not all processes include a temporal dimension, we consider SI as such - though this does not imply that SI is a linear process.

11 A process is completed when the interaction of different entities results in a given end state. For example, in the scientific process of diffusion the end state is an equal dispersion of particles.

12 Here, we diverge very slightly from Haddock and Tornaghi, who identify 'institutionalization' as the engine of SI. See Haddock, Serena Vicari and Tornaghi, Chiara. (2013) A Transversal Reading of Social Innovation in European Cities. In Frank Moulaert, Diana MacCallum, Abid Mehmood \& Hambouch

Abdelillah (eds.) The International Handbook on Social Innovation: Collective Action, Social Learning and 
Transdisciplinary Research. Northampton, MA: Edward Elgar. While we agree strongly with much of Haddock and Tornaghi's argument, we seek to build a theory of SI that acknowledges the dialectic between agency and structure embodied in social action - acknowledging the arguments of Leubolt, Bernhard, Novy, Andreas \& Beinstein, Barbara. (2007). Governance and Democracy - KATARSIS Survey Paper.

Vienna: Wirtschaftuniversitât Wien/CRISES; Cajaiba-Santana, G. (2014). Social Innovation: Moving the Field Forward. A Conceptual Framework. Technological Forecasting \& Social Change 82, 42-51. On an SI-specific note, we propose the dual engine framework as a way to account for "dialectical tension between innovation and institutionalisation of SC". See Cabeza, Marisol García, Miquel, Marc Pradel, and Anglada, Santiago Eizaguirre. (2009). Citizens' Creative Strategies Facing Social Exclusion: Towards Innovation in Local Governance? Regional Studies Association Annual Conference at p.2.

${ }^{13}$ Rouf, Kazi Abdur. (8 September 2011). Green Microfinance Promoting Green Enterprise Development. International Journal of Research Studies in Management 1(1), 85-96.

${ }^{14}$ Canadian Broadcasting Corporation (CBC) News. (2 November 2015). Cosmetologists Given Training to Spot Family Violence. CBC News, at http://www.cbc.ca/news/canada/new-brunswick/family-violencepolicecosmetology-1.3299750.

${ }^{15}$ The move to instrumentalize social relationships toward a given objective is a defining characteristic of SI, as argued by Fox, C. \& Grimm, R. (2015). The Role of Social Innovation in Criminal Justice Reform and the Risk Posed by Proposed Reforms in England and Wales. Criminology and Criminal Justice 15(1). ${ }^{16}$ Institutional theorists acknowledge that "institutions set bounds on rationality by restricting the opportunities and alternatives we perceive and, thereby, increase the probability of certain types of behaviour". See Barley, Stephen R. and Tolbert, Pamela S. (1997). Institutionalization and Structuration:

Studying the Links between Action and Institution. Organization Studies 18(1) at p.94.

${ }^{17}$ Fontan, Jean-Marc. (2008). Becoming a Social Entrepreneur in Canada/Enquête Auprès d'Entrepreneurs Sociaux. Victoria: Canadian Social Economy Hub; Martin, Roger and Osberg, Sally. (2007). Social Entrepreneurship: the Case for a Definition. Stanford Social Innovation Review.

${ }^{18}$ For works that define a 'social entrepreneur', see, among others, Terjesen, Siri, Lepoutre, Jan, Justo, Rachida, and Bosma, Niels. (2009). Report on Social Entrepreneurship. Global Entrepreneurship Monitor; OECD Centre d'Analyse Strategique. (n.d.). L'entrepreneuriat Social en France - Réflexions et Bonnes Pratiques. OECD; Social Entrepreneurs Ireland. (2014). Social Entrepreneurship - Considerations for Policy Makers and Practitioners. Social Entrepreneurs Ireland, at http://socialentrepreneurs.ie/assets/2014/07/SocialEntrepreneurship-Considerations-for-Policy-Makersand-Practitioners.pdf.

${ }^{19}$ Some definitions of social entrepreneur require that the actor adopt a market orientation. This view is often associated with Schumpeterian entrepreneurship. See, for example, Zaeri, Mehran. (2014). A Theoretical Study of Social Entrepreneurship. Journal of Asia Entrepreneurship and Sustainability 10(2), 3-

37; Volkmann, Christine, Tokarski, Kim, and Ernst, Kati (eds.). Social Entrepreneurship and Social Business: an Introduction and Discussion with Case Studies. Springer Gabler. We do not restrict ourselves to this view, and are not alone in taking this approach. For example, Barinaga highlights discursive and community rationality as alternatives to economic rationality defining the social dimension of social entrepreneurship. See Barinaga, Ester. (2013). Politicising Social Entrepreneurship - Three Social Entrepreneurial Rationalities Toward Social Change. Journal of Social Entrepreneurship 4(3), 347-372. ${ }^{20}$ One such example is Arindom, Biswas. (2014). Socioeconomic Conditions of Women Entrepreneurs with Special Reference to Cooch Behar District in West Bengal. Indian Streams Research Journal 4(11).

${ }^{21}$ See, for example, Mehran, Z. (2014). A Theoretical Study of Social Entrepreneurship. Journal of Asia Entrepreneurship and Sustainability 10(2), 3-37; Copeland, Paul and James, Scott. (2014). Policy Windows, Ambiguity and Commission Entrepreneurship: Explaining the Launch of the European Union's Economic Reform Agenda. Journal of European Public Policy 21(1), 1-19.

${ }^{22}$ The authors argue that social networks can be considered as a bridge between the meso- and macrolevels of analysis. Dufays, Frédéric and Huybrechts, Benjamin. (2014). Connecting the Dots for Social Value: a Review on Social Networks and Social Entrepreneurship. Journal of Social Entrepreneurship 5(2), 214-237. 
${ }^{23}$ One such example is London, Manuel. (2010). Understanding Social Advocacy: an Integrative Model of Motivation, Strategy, and Persistence in Support of Corporate Social Responsibility and Social Entrepreneurship. Journal of Management Development 29(3), 224-245.

${ }^{24}$ Baierl, Ronny, Grichnik, Dietmar, Spörrie, Matthias, and Welpe, Isabell. (2014). Antecedents of Social Entrepreneurial Intentions: the Role of an Individual's General Social Appraisal. Journal of Social Entrepreneurship 5(2), 123-145.

${ }^{25}$ Volkmann et al. supra note 19; Dacin, P.A., Dacin, M.T., and Matear M. (2010). Social

Entrepreneurship: Why We Don't Need a New Theory and How We Move Forward From Here. Academy of Management Perspectives 24(3), 37-57.

${ }^{26}$ For example, Leubolt et al. offer three examples of how SCS have been deployed for the social purpose of combatting exclusionary dynamics.

${ }^{27}$ Mumford, M. D. (2003). Where Have We Been, Where Are We Going? Taking Stock in Creativity Research. Creativity Research Journal, 15(2-3), 107-120.

${ }^{28}$ Sternberg, R. J., \& Lubart, T. I. (1999). The Concept of Creativity: Prospects and Paradigms. In R. J. Sternberg (Ed.), Handbook of Creativity. Cambridge, England: Cambridge University Press, p.3-15.

${ }^{29}$ Kluger, A. N., \& DeNisi, A. (1996). The Effects of Feedback Interventions on Performance: a Historical Review, a Meta-analysis, and a Preliminary Feedback Intervention Theory. Psychological Bulletin, 119(2), 254.

${ }^{30}$ Small, Michael. (1997). Business Education, Values and Beliefs. Teaching Business Ethics 1, 53-61. ${ }^{31}$ Manohar, S. Sai and Pandit, Shiv R. (2014). Core Values and Beliefs: a Study of Leading Innovation Organizations. Journal of Business Ethics 125, 667-680.

32 Westley, F. (2008a). What is Social Innovation. Presentation for SiG@Waterloo. University of Waterloo; (2008b). The Social Innovation Dynamic. SiG@Waterloo.

${ }_{33}$ OECD. (2010). Measuring Innovation: a New Perspective. Paris: OECD, at Chapter 2.

${ }^{34}$ Marcy, Richard T., and Mumford, M. (2007). Social Innovation: Enhancing Creative Performance through Causal Analysis. Creativity Research Journal 19(2-3), 123-140.

35 Finnemore, M. \& Sikkink, K. (1998). International Norm Dynamics and Political Change. International Organization 52, 887-917.

${ }^{36}$ Restrepo, Juan Manuel and Lee, Eliza. (2015). Institutional Embeddedness and the Scaling-up of Collaboration and Social Innovation. Policy and Politics 43(3), 459-471; Phipps, David, Hewitt, Allyson, Nichols, Naomi, and Provencal, Johanne. (2013). Knowledge Mobilization, Collaboration, and Social Innovation: Leveraging Investments in Higher Education. Nonprofit and Social Economy Research 4(1), 25-42.

${ }^{37}$ Calgary UnitedWay. (n.d.). "What is the Process of Collaborative Social Innovation?" Calgary's Network for Collaborative Social Innovation Backgrounder Series No.3, at http://www.calgaryunitedway.org/main/images/leadingboldy $/ 3 \% 20$ toolkit $\% 20$ the $\% 20$ process $\% 20$ of $\% 20 \mathrm{csi} \% 20 \mathrm{feb}$ \%2026.pdf.

${ }^{38}$ Murray, Paul and Ma, Steve. (2015). The Promise of Lean Experimentation. Stanford Social Innovation Review, at http://ssir.org/articles/entry/the promise of lean_experimentation.

39 This is exemplified by the discussion of Moore and Westley on 'institutional entrepreneurship' throughout the social innovation process. See Moore, M. L., \& Westley, F. (2011). Surmountable Chasms:

Networks and Social Innovation for Resilient Systems. Ecology and Society 16(1), 5.

40 Oil sands workers are routinely tested for mind-altering substances such as alcohol and drugs, as such substances pose a safety risk on site. However, marijuana remains present in test results for weeks while other, more harmful, drugs such as cocaine leave the system much more quickly - sometimes, within a day. As such, the institution of random on site drug testing, as currently configured, creates an incentive for workers to use more harmful drugs during their days off, exacerbating existing substance abuse problems in these communities.

${ }^{41}$ British Broadcasting Corporation (BBC) News. (27 July 2015). Pee-proof: San Francisco Trials Paint that Repels Urine. BBC News, at http://www.bbc.com/news/world-us-canada-33682342.

42 Bennett-Smith, Meredith. (5 November 2012). India Sanitation: Volunteers Beat Drums to Shame Men Who Pee, Defecate in Public in Rajasthan. Huffington Post, at http://www.huffingtonpost.com/2012/11/05/volunteers-beat-drums-to-shame-men-whp-pee-in-publicindian- 
rajasthan_n_2079311.html; BBC News. (11 March 2015). India: 'Walls of Shame' Against Outdoor Defecation. BBC News, at http://www.bbc.com/news/blogs-news-from-elsewhere-31831559.

${ }_{43}$ Moore and Westley supra note 39.

${ }^{44}$ Drawn from work on the norm life cycle. See Finnemore \& Sikkink supra note 35.

${ }^{45}$ The diffusion of innovation literature identifies five different categories of adopters: innovators, early adopters, early majority, late majority, and laggards. See Rogers, E.M. (1962). Diffusion of Innovations. New York: Free Press. Diffusion refers to "any process where prior adoption of a trait or practice in a population alters the probability of adoption for remaining non-adopters." See Strang, David. (1991). Adding Social Structure to Diffusion Models: an Event History Framework. Sociological Methods and Research 19(3), 324-353.

${ }^{46}$ Dillard, Jesse F., Rigsby, John T. and Goodman, Carrie. (2004). The Making and Remaking of Organization Context: Duality and the Institutionalization Process. Accounting, Auditing and Accountability Journal 17(4), 506-542; Wendt, A. (1992). Anarchy is What States Make of it: the Social Construction of Power Politics. International Organization 46(2), 391-425 at p.399. We may also consider DiMaggio and Powell's three types of isomorphism (coercive, mimetic, and normative) as relevant here, although normative isomorphism occurs also within the emergence phase. See DiMaggio, Paul J. and Powell, Walter W. (1983). The Iron Cage Revisited: Institutional Isomorphism and Collective Rationality in Organizational Fields. American Sociological Review 48(2), 147-160.

${ }^{47}$ Haddock \& Tornaghi supra note 12 at p. 265.

${ }^{48}$ As in the norm life cycle, this stage is characterized by imitation. See Finnemore and Sikkink supra note 35. Coercive isomorphism may be dominant during this point in the adoption phase. See DiMaggio and Powell supra note 46.

${ }^{49}$ If this occurs, mimetic isomorphism will be dominant, reinforcing the SCS through habit. See DiMaggio and Powell supra note 46; Etzioni, Amitai. (2000). Social Norms: Internalization, Persuasion, and History. Law and Society Review 34(1), 157-178; Maltseva, Kateryna. (2015). Norm Internalization and the Cognitive Mechanism of Cultural Consonance. International Journal of Culture and Mental Health 8(3), 255-273; Kyoko, Hatakeyama. (2014). Japan's Peacekeeping Policy: Strategic Calculation or Internalization of an International Norm? The Pacific Review 27(5), 629-650.

${ }^{50}$ On networks see Granovetter, Mark S. (1973). The Strength of Weak Ties. American Journal of Sociology 78(6), 1360-1380; Newman, Mark. (2010). Networks: an Introduction. New York: Oxford University Press. Network analysis is a method that has been developed to study network composition and density. As an example of a SI text that discusses networks, see Moore and Westley supra note $39 .{ }^{51}$ Here, one might think of the work of Benedict Anderson. See Anderson, Benedict. (2006). Imagined Communities: Reflections on the Origin and Spread of Nationalism. London: Verso.

${ }^{52}$ DiMaggio, Paul J. and Powell, Walter W. (1983). The Iron Cage Revisited: Institutional Isomorphism and Collective Rationality in Organizational Fields. American Sociological Review 48(2), 147-160. DiMaggio and Powell define an organizational field as "sets of organizations that, in the aggregate, constitute a recognized area of institutional life; key suppliers, resource and product consumers, regulatory agencies, and other organizations that produce similar services or products". ${ }^{53}$ OECD. "What is Social Capital?" OECD Insights: Human Capital, at http://www.oecd.org/insights/37966934.pdf.

${ }^{54}$ Putnam, Robert. (2000). Bowling Alone: the Collapse and Revival of American Community. Simon and Schuster.

${ }^{55}$ Steger, Manfred, McLean, Scott and Schultz, David. (2002). Social Capital: Critical Perspectives on Community and "Bowling Alone". New York: NYU Press.

${ }^{56}$ Fox and Grimm supra note 15 p.74.

${ }^{57}$ Bardis supra note 10.

${ }^{58}$ Cox discusses these as the three forces of hegemony, as characteristics that interact to structure world order. See Cox, R. (1986). Social Forces, States and World Orders: Beyond International Relations Theory.

In Keohane (ed.) Neorealism and its Critics. New York: Columbia University Press.

${ }^{59}$ For a recent discussion of how social structure relates to power, see Elder-Vass, Dave. (2011). The Causal Power of Social Structures: Emergence, Structure and Agency. Cambridge: Cambridge University Press.

${ }^{60}$ For an example of how social structure affects changing practices, see Stritzel's critique of the Copenhagen School in international relations theory. In this work, Stritzel identifies the existing discourse and an actor's 
positional power as factors that influence whether a threat claim (an attempt to view a problem as a security issue when it was previously not considered as such) will be accepted. Stritzel, H. (2007). Towards a Theory of Securitization: Copenhagen and Beyond. European Journal of International Relations 13(3), 357-383.

${ }^{61}$ As noted above, Haddock and Tornaghi have previously described institutionalization as an engine of social innovation. Haddock and Tornaghi supra note 12.

${ }^{62}$ North, Douglass. (1990). Institutions, Institutional Change, and Economic Performance. Cambridge: Cambridge University Press.

${ }^{63}$ Dillard et al. supra note 46.

${ }^{64}$ Wendt, A. (1992). Anarchy is What States Make of it: the Social Construction of Power Politics.

International Organization 46(2), 391-425 at p.399.

${ }^{65}$ Duffield, J. (2007). What Are International Institutions? International Studies Review 9, 1-22 ${ }^{66}$ Ikenberry, J. (1998/1999). Institutions, Strategic Restraint, and the Persistence of American Postwar Order. International Security 23(3), 43-78 at p.52.

${ }^{67}$ Koremenos, B., Lipson, C. \& Snidal, D. (2001). The Rational Design of International Institutions. International Organization 55(4), 761-799 at p.762.

${ }^{68}$ Stated another way, "implicit in [...the] formulation [of institutions], there is a hierarchy of institutional influence where the economic and political level provides the foundations for organizational field level institutions, and the organizational field provides the context for the institutions confronted by and embedded in organizations." See Dillard et al. supra note 46.

${ }^{69}$ Dillard et al. supra note 46.

${ }^{70}$ Tripathi, Salil. (17 October 2006). Microcredit Won't Make Poverty History. The Guardian, at http://www.theguardian.com/business/2006/oct/17/businesscomment.internationalaidanddevelopment. ${ }^{71}$ For an explanation of social impact bonds and a review of the evidence in favor of and against them, see Pue, Kristen, Vandergeest, Christian, Literovich, Ian, Shafiq, Seher and Simmonds, Faye. (June 2014). Social Entrepreneurship - Considerations for Policy Makers and Practitioners. Social Entrepreneurs Ireland.

${ }^{72}$ See, for example, Rochon, Louis-Philippe. (20 June 2015). Social Impact Bonds: Another Attempt at Privatizing Government? CBC News, at http://www.cbc.ca/news/canada/manitoba/social-impact-bondsanother-attempt-atprivatizing-government-1.3120879.

${ }^{73}$ Len, Arthur. (2013). Reflections on the Form and Content of Participatory Action Research and Implications for Social Innovation Research. In Moulaert et al. (eds.) The International Handbook on Social Innovation: Collective Action, Social Learning and Transdisciplinary Research. Northampton, MA: Edward Elgar; Westley, Frances. (October 2008). The Social Innovation Dynamic. SiG@Waterloo; Smith, Adrian. (October 15, 2014). Considering Social Innovation from a Social Movement Perspective.

TRANSIT Social Innovation, at http://www.transitsocialinnovation.eu/blog/considering-social-innovationfrom-asocial-movement-perspective. On institutionalization as a catalyst of identity change, see also Risse, T. (2000). "Let's Argue!": Communicative Action in World Politics. International Organization 54(1), 139. Risse discusses institutionalization as a facilitator of deliberation through the construction of a common lifeworld (which enables individuals to communicate in a meaningful way. He mentions this in regards to the possibility of deliberation in international politics.

${ }^{74}$ European Commission. (2015). European Social Innovation Competition. European Commission, at http://ec.europa.eu/growth/industry/innovation/policy/social/competition/index en.htm.

${ }^{75}$ Westley, F. (2013). Social Innovation and Resilience: How One Enhances the Other. Stanford Social Innovation Review, Summer 2013. Resilience studies focus on continuous cycles of release, reorganization, growth, and consolidation that occur within a complex adaptive system.

${ }^{76}$ See Westley supra note 68; Moore and Westley supra note 39.

${ }_{77}^{77}$ Moore and Westley supra note 39.

${ }^{78}$ Goering, Paula, Veldhuizen, Scott, Watson, Aimee, Adair, Carol, Kopp, Brianna, Latimer, Eric, Nelson, Geoff, MacNaughton, Eric, Streiner, David, Aubry, Tim. (2014) National Final Report: Cross-Site At Home/Chez Soi Project. Calgary, AB: Mental Health Commission of Canada. 
${ }^{79}$ Medicine Hat Community Housing Society (MHCHS). (2015). At Home in Medicine Hat: Our Plan to End Homelessness Year 5 Progress Report. MHCHS, at http://production.mhchs.ca/static/mainsite/files/housingdevelopment/Year-5-Progress-Report.pdf.

${ }^{80}$ Kerr, Thomas, McPherson, Donald and Wood, Evan. (2008). Establishing North America's First Safer Injection Facility: Lessons from the Vancouver Experience. In Alex Stephens (ed.) Crossing Frontiers:

International Developments in the Treatment of Drug Dependence. Brighton: Pavilion Publishing, 109-129.

${ }^{81}$ Stueck, Wendy. (11 May 2011). The Arguments For and Against Vancouver's Supervised Injection Site. The Globe and Mail, at http://www.theglobeandmail.com/news/british-columbia/the-arguments-for-andagainstvancouvers-supervised-injection-site/article596153/.

${ }^{82}$ Centre for Social Innovation (CSI). (October 2010). Envisioning Social Innovation in Ontario. CSI and Ontario Nonprofit Network.

${ }^{83}$ Boyd, Neil. (2013). Lessons from INSITE, Vancouver's Supervised Injection Facility: 2003-2012.

Drugs: Education, Prevention and Policy 20(3), 234-240.

${ }^{84}$ See, for example, DeJong, William and Winsten, Jay. (1990). The Harvard Alcohol Project: a

Demonstration Project to Promote the "Designated Driver". Center for Health Communication, Harvard School of Public Health; National Highway Traffic Safety Administration (NHTSA). (1987). The Review and Assessment of Designated Driver Programs as an Alcohol Countermeasure Approach. U.S. Department of Transportation NHTSA Report DOT HS 807 108; The Globe and Mail. (29 May 1985). Hiram Plan Seeks to Curb Drunk Drivers. The Globe and Mail section B8; Donovan, Kevin. (12 November 1985). Designated Driver Program will Feature Free Pop. Toronto Star section E9.

${ }^{85} \mathrm{See}$ http://foodcloud.net/.

${ }^{86}$ Fox, C. \& Grimm, R. (2015). The Role of Social Innovation in Criminal Justice Reform and the Risk Posed by Proposed Reforms in England and Wales. Criminology and Criminal Justice 15(1); Murray, Caulier-Grice \& Mulgan supra note 6; European Commission Regional and Urban Policy. (2013). Guide to Social Innovation. European Commission; Centre for Social Innovation. (October 2010) Envisioning Social Innovation in Ontario. CSI and Ontario Nonprofit Network.

87 Stigendal, Mikael. (2010). Cities and Social Cohesion: Popularizing the Results of Social Polis. Malmö, Sweden: Malmö University Publications in Urban Studies, at http://siresearch.eu/sites/default/files/Cities_and_Social_Cohesion_-_final_web_.pdf; European Commission. (n.d.). Social Innovation. European Commission Employment, Social Affairs and Inclusion, at http://ec.europa.eu/social/main.jsp?catId=1022; European Commission. (2 February 2015). Social Innovation. European Commission Enterprise and Industry, Innovation Policy, at http://ec.europa.eu/enterprise/policies/innovation/policy/social-innovation/index en.htm; Murray, CaulierGrice \& Mulgan supra note 6; Phills, J.A., Deigelmeier, K. \& Miller, D.T. (2008). Rediscovering Social Innovation. Stanford Social Innovation Review, 6(4), 34-43.

${ }^{88}$ Bonifacio, M. (2014). Social Innovation: a Novel Policy Stream or a Policy Compromise? An EU Perspective. European Review 22(1), 145-169. In a similar line of thinking, Linsey McGoey associates social innovation with neoliberalizing shifts causing the turn to 'philanthrocapitalism'. See McGoey, L. (2014). The Philanthropic State: Market-State Hybrids in the Philanthrocapitalist Turn. Third World Quarterly 35(1), 109-125.

89 Hulgård, Lars and Shajahan, P.K. (2013). Social Innovation for People-Centred Development. In Frank Moulaert, Diana MacCallum, Abid Mehmood \& Hambouch Abdelillah (eds.) The International Handbook on Social Innovation: Collective Action, Social Learning and Transdisciplinary Research. Northampton, MA: Edward Elgar.

90 Bureau of European Policy Advisers (BEPA). (2011). Empowering People, Driving Change: Social Innovation in the European Union. Luxembourg: Publications Office of the European Union. doi:

10.2796/13155; Bonifacio supra note 88.

91 Ibid.

92 Leubolt, Bernhard, Novy, Andreas \& Beinstein, Barbara. (2007). Governance and Democracy - KATARSIS Survey Paper. Vienna: Wirtschaftuniversitât Wien/CRISES.

93 Sen, A. (1999). Development as Freedom. Toronto: Random House. 
94 Parra, Constanza. (2013). Social Sustainability: a Competing Concept to Social Innovation? In Frank Moulaert, Diana MacCallum, Abid Mehmood \& Hambouch Abdelillah (eds.) The International Handbook on Social Innovation: Collective Action, Social Learning and Transdisciplinary Research. Northampton, MA: Edward Elgar.

95 Klievink, B. \& Janssen, M. (2014). Developing Multi-layer Information Infrastructures: Advancing Social Innovation through Public-Private Governance. Information Systems Management 31, at p.240.

96 For a recent work in this area, see Ries, Eric. (2011). The Lean Startup. New York: Crown Business. Social innovation has been explicitly connected to this literature in, for example, KPMG. (2014). Breaking Through: How Corporate Social Innovation Creates Business Opportunity. KPMG.

97 For an explanation of the social economy, see Quarter, J., Mook, L. \& Ryan, S. (2010). Researching the Social Economy. Toronto: University of Toronto Press.

98 European Commission Regional and Urban Policy. (2013). Guide to Social Innovation. European Commission.

99 Mulgan, Geoff. (2007). Social Innovation: What it is, Why it Matters and How it Can Be Accelerated.

The Young Foundation.

${ }^{100}$ See, for example, Loogma, K., Tafel-Viia, K. \& Ümarik, M. (2012). Conceptualising Educational Changes: a Social Innovation Approach. Journal of Education Change 14, 283-301; BEPA supra note 90; Fox and Grimm supra note 15; Bonifacio supra note 88.

${ }^{101}$ This definition is from Moulaert et al. supra note 1. Although the European Commission's definition is different and also is widely used, there is not much analytical distance between the two definitions.

102 Jessop, B., Moulaert, F., Hulgård, L. \& Hamdouch, A. (2013). Social Innovation Research: A New Stage in Innovation Analysis? In Moulaert et al. (eds.) The International Handbook on Social Innovation: Collective Action, Social Learning and Transdisciplinary Research. Northampton, MA: Edward Elgar.

${ }^{103}$ See, for example, Murray, Caulier-Grice and Mulgan supra note 6; European Commission Regional and Urban Policy. (2013). Guide to Social Innovation. European Commission; Mulgan, Geoff. (2007). Social Innovation: What it is, Why it Matters and How it Can Be Accelerated. The Young Foundation.

${ }^{104}$ Loogma et al. supra note 100.

${ }^{105}$ Murray, Caulier-Grice \& Mulgan supra note 6 at p.3.

${ }^{106}$ Loogma et al. supra note 100; Murray, Caulier-Grice and Mulgan supra note 6.

${ }^{107}$ For example, "impact, scale and durability" or broad impact. See Social Innovation Generation (SiG). (updated 2015). "Primer", SiG, at http://www.sigeneration.ca/home/resources/primer/; Westley, F. (2008a).

What is Social Innovation. Presentation for SiG@Waterloo. University of Waterloo; (2008b). The Social Innovation Dynamic.SiG@Waterloo.

${ }^{108} \mathrm{Pol}$ and Ville supra note 8.

${ }^{109}$ Because it generally includes a normative requirement that some kind of social 'good' occurs, social innovation has come to be viewed as a category of desirable social change. Defining social innovation in this manner is to employ the term so as to produce meaning, rather than simply describing it. While arguably all uses of language are productive, the link between social innovation and 'good' outcomes, as endorsed in the social benefit claim, allows for the term to be imbued as a sort of badge of approval for any change that is seen as 'good' by the actors applying the label. For a discussion of productive language in regards to a concept, see the example of terrorism. Huysmans, J. (1998). Security! What Do You Mean?

From Concept to Thick Signifier. European Journal of International Relations 4(2), 226-255.

${ }^{110}$ Evidence of this practice is demonstrated by a search for works discussing "social innovation" that we conducted on the Factiva data tool on 2 March 2015. For more on this, see Appendix 2.

${ }^{111}$ For example, the OECD places special emphasis on the creation of jobs. See Committee for Scientific and Technological Policy (CSTP). (2011). Fostering Innovation to Address Social Challenges. Paris:

OECD.

${ }^{112}$ Caulier-Grice et al. supra note 6 at p.15.

${ }^{113}$ For a simple discussion of this and other methodological debates, see Howard, P. (2010). Triangulating Debates within the Field: Teaching International Relations Research Methodology. International Studies Perspectives 11(4), 393-408. 
${ }^{114}$ Constructivism in international relations theory has faced similar criticisms (that it was ill equipped to study 'bad norms') in the past. On constructivism and bad norms, see, for example, Price, R. (2008). Moral Limit and Possibility in World Politics. International Organization 62; Checkel, J. (1998). The Constructivist Turn in International Relations Theory. World Politics 50(2).

${ }^{115}$ Fox, C. \& Grimm, R. (2015). The Role of Social Innovation in Criminal Justice Reform and the Risk Posed by Proposed Reforms in England and Wales. Criminology and Criminal Justice 15(1) at p.66.

116 BEPA supra note 90.

117 This alludes to Albert Hirschman's use of the term 'monoeconomics' to describe a cleavage amongst development economists. See Hirschman, A. (2013, previously published). The Rise and Decline of Development Economics. In Jeremy Adelman (ed.) The Essential Hirschman. Princeton, NJ: Princeton University Press, at p.52. Just as adherents to monoeconomics hold that the discipline of "economics consists of a number of simple, yet "powerful" theorems of universal validity: there is only one economics", mono-innovation holds that a single theory of innovation can apply to all subcategories of innovation, including social innovation.

${ }^{118}$ Schumpeter, J. (1947). Capitalism, Socialism, and Democracy. New York: Harper.

119 Ibid. See also Baumol, W. (2002). The Free-Market Innovation Machine: Analyzing the Growth Miracle of Capitalism. Princeton, NJ: Princeton University Press; Hanusch, H. (ed.). (1988). Evolutionary Economics: Applications of Schumpeter's Ideas. New York: Cambridge University Press; Sloth Anderson, E. (2011). Joseph A. Schumpeter: A Theory of Social and Economic Evolution. New York: Palgrave Macmillan.

120 The supposition, here, is that innovation - whether defined conventionally as a market-specific phenomenon or more broadly as novel ideas - involves social processes. Some works associated with this claim include: Lopez Cerezo, J.A. and Gonzalez, M.I. (2013). Social Crossroads of Innovation. Isegoria 48, 11-24; Bhatt, P. and Altinay, L. (2013). How Social Capital is Leveraged in Social Innovations Under Resource Constraints. Management Decision 51(9) 1772-1792; Grützmann, A. Felício Macedo, F.M. and Zambalde, A.L. (2013). Knowledge Management and Innovation: the Role of Virtual Social Networks in Innovative Consumer Behavior. Journal of Technology Management and Innovation 8, 73; Huggins, R., Johnston, A. and Thompson, P. (2012). Network Capital, Social Capital and Knowledge Flow: How the Nature of Inter-organizational Networks Impacts on Innovation. Industry and Innovation 19(3), 203-232; Chiu, Y.T.H. and Lee, T.L. (2012). Structural Embeddedness and Innovation Performance: Capitalizing on Social Brokerage in High-tech Clusters. Innovation-Management Policy and Practice 14(3), 337-348; Zhang, H., Wei, X. and Kang, K. (2012). A Study of the Effects of Social Capital on Inter-firm Knowledge Transfer and Innovation Performance. In Proceedings of the 2010 International Conference on Information Technology and Scientific Management, 20-21 December 2010, Tianjin Polytechnic University, Tianjin, China, 819823; Rogers, E.M. (2003). Diffusion of Innovations, $5^{\text {th }}$ ed. New York: Free Press.

${ }^{121}$ Within this conceptual frame, "innovation as a social phenomenon" can be understood in two different ways: as co-developmental and in terms of a social category of innovation. See Klievink, B. \& Janssen, M. (2014). Developing Multi-layer Information Infrastructures: Advancing Social Innovation through PublicPrivate Governance. Information Systems Management 31, p.241-2; Shapson, S. (2009). Leading Wisely, Leading Boldly, Leading Collectively. Social Innovation: University and Community Partnerships.

Toronto: York University, p.5; Loogma et al. supra note 100; Cajaiba-Santana, G. (2014). Social Innovation: Moving the Field Forward. A Conceptual Framework. Technological Forecasting and Social Change 82, 42-51; Lubelcovà, G. (2012). Social Innovations in the Context of Modernization. Sociologia 44(3), 291-313; Fedołova, V.G. (2010). Social Innovations as the Basis of Society Modernization Process. Voprosy Filosofii 10, 316; Echeverria, J. (2008). The Oslo Manual and Social Innovation. Arbor-Ciencia Pensamiento y Cultura 184(732), 609-618; He, A.J. and Qiao, L. (2008). Innovation and Entrepreneurship.

In Proceedings of Academy of Innovation and Entrepreneurship, 27-29 March 2008, Tsinghua University, Beijing, China, 164-166; Jamali, D., Yianni, M., and Abdallah, H. (2011). Strategic Partnerships, Social Capital and Innovation: Accounting for Social Alliance Innovation. Business Ethics - A European Review 20(4), 375-391; Rexhepi, G., Kurtishi, S., and Bexheti G. (2013). Corporate Social Responsibility (CSR) and Innovation the Drivers of Business Growth? Procedia: Social and Behavioral Sciences 75, 532-541; Mumford, M.D. \& Moertl, P. (2003). Cases of Social Innovation: Lessons from Two Innovations in the $20^{\text {th }}$ Century. Creativity Research 
Journal 15(2\&3), 261-266; Hamalainen, T.J. \& Heiskala, R. (eds.) (2007). Social Innovations, Institutional Change and Economic Performance. Cheltenham: Edward Elgar.

${ }^{122}$ Loogma et al. supra note 100.

${ }^{123}$ See, for example, the section in Păunescu's study pertaining to innovation performance. Păunescu supra note 2 at p.111.

${ }^{124}$ Murray, Caulier-Grice \& Mulgan supra note 6; Păunescu supra note 2.

${ }^{125}$ Haddock and Tornaghi supra note 12.

${ }^{126}$ Finnemore \& Sikkink supra note 35.

${ }^{127} \mathrm{Jessop}$ et al. supra note 102.

${ }^{128}$ Giddens, Anthony. (1986). The Constitution of Society: Outline of the Theory of Structuration.

University of California Press; Wendt, A. (1987). The Agent-Structure Problem in International Relations Theory. International Organization 41(3), 335-370. Structure and agency are mutually constitutive and yet ontologically distinct, which means that we need to study both in order to understand SI.

${ }^{129}$ Jessop et al. supra note 102 .

${ }^{130}$ We identified these five research communities in our modularity analysis. See Appendix I.

${ }^{131}$ For an example of a stages of social innovation approach, see Murray, Caulier-Griece \& Mulgan supra note 6; BEPA supra note 90.

${ }^{132}$ Mulgan, Geoff. (2012). Social Innovation Theories: Can Theory Catch Up With Practice. In Franz Hans-Werner Josef Hochgerner and Jürgen Howaldt. (eds.) Challenge Social Innovation: Potentials for Business, Social Entrepreneurship, Welfare and Civil Society. New York: Springer, pp. 19-42. ${ }^{133}$ For example, calls for a government-supported social innovation lab that aims to build prototypes for new innovations with the goal of scaling, as has been recommended by the Centre for Social Innovation, directs action towards certain types of socially creative strategies that fit within the model of a social enterprise, while it might leave out targeted norm changes or other types of mobilization-based strategies that rely less on prototyping and piloting. Moreover, the imperative of 'scaling' may undermine the risk tolerance that may be necessary for encouraging the development of new socially creative strategies.

${ }^{134}$ For example, the Open Book of Social Innovation lists 527 ways to support social innovation, with no comparative analysis of these strategies. See Murray, Caulier-Grice \& Mulgan supra note 6; CajaibaSantana also discusses this phenomenon at p.42-43. See Cajaiba-Santana, G. (2014). Social Innovation: Moving the Field Forward. A Conceptual Framework. Technological Forecasting \& Social Change 82, 4251.

${ }^{135}$ Von der Porten, Suzanne. (2014). Lyell Island (Athlii Gwaii) Case Study: Social Innovation by the Haida Nation. American Indian Culture and Research Journal 38(3), 85-106.

${ }^{136}$ Murray, Caulier-Grice, Mulgan supra note 6.

${ }^{137}$ The search was narrowed to include articles, book reviews, reviews, proceedings papers, and book chapters. Excluded materials were editorial material, letters, and meeting abstracts.

${ }^{138}$ The analysis of research areas should be used as a general indication of publication topic only. Research areas are determined by journal, and so may not be entirely accurate when measuring a cross-disciplinary topic such as social innovation. Further, some journals are assigned more than one research area, which may distort the results. The figure shows only highly cited publications (approximately $45 \%$ of social innovation publications, and $1 \%$ of total publications in the network).

${ }^{139}$ Available for free at http://gephi.github.io/.

${ }^{140}$ Modularity is a measure of the structure of a network. It measures the "strength" or degree of connection between nodes in a network, identifying communities that are tied more closely. The method used by this modularity analysis was based on Blondel, V. D., Guillaume, J. L., Lambiotte, R., \& Lefebvre, E. (2008). Fast Unfolding of Communities in Large Networks. Journal of Statistical Mechanics: Theory and

Experiment, 2008(10), P10008.; and Lambiotte, R., Delvenne, J. C., \& Barahona, M. (2008). Laplacian Dynamics and Multiscale Modular Structure in Networks. Transactions on Network Science and Engineering 1(2), p. 76-90. Analysis used a resolution of 4 and 8.

${ }^{141}$ The 396 publications average 35.6 citations each. They cite 12059 external publications, for a total of 14107 citations. 
142 This result was achieved by conducting modularity analyses with resolution 4 and resolution 8 , and comparing the results to cross reference community identification and avoid problems arising from minimum resolution. Note that Community E has been separated from Community D due to a weak linkage, despite identical colour coding. ${ }^{143}$ For example, Research Community A contains 5 highly cited articles by Michael Mumford, while Research Community B contains four highly cited articles by Frank Moulaert. See Mumford (2002) supra note 2; Mumford, Michael D. (2003). Where Have We Been, Where are We Going? Taking Stock in Creativity Research. Creativity Research Journal (15)3, 107-120.; Mumford, Michael and Mobley, Michele and Reiter-Palmon, Roni and Uhlman, Charles and Doares, Lesli. (1991). Process Analytic Models of Creative Capacities. Creativity Research Journal 4(2), 91-122.; Mumford, M. D., Schultz, R. A., \& Van Doorn, J. R. (2001). Performance in Planning: Processes, Requirements, and Errors. Review of General Psychology, 5(3), 213.; Mumford, Michael D., Baughman, Wayne A., Sager, Christopher E. (2003).

Critical Creative Processes. In Runco, Mark A. (ed), Perspectives on Creativity Research. Cresskill, NJ: Hampton Press, p.19-68; Moulaert, F., Martinelli, F., Swyngedouw, E., \& Gonzalez, S. (2005). Towards Alternative Model(s) of Local Innovation. Urban Studies, 42(11), 1969-1990.; Moulaert, F., \& Sekia, F. (2003). Territorial Innovation Models: a Critical Survey. Regional Studies 37(3), 289-302.; Moulaert, F., Rodríguez, A., \& Swyngedouw, E. (eds.). (2003). The Globalized City: Economic Restructuring and Social Polarization in European Cities: Economic Restructuring and Social Polarization in European Cities. New York: Oxford University Press; Moulaert, F., \& Nussbaumer, J. (2005). The Social Region Beyond the Territorial Dynamics of the Learning Economy. European Urban and Regional Studies 12(1), 45-64. ${ }^{144}$ Geography was assessed by examining the home university (if any) of the most frequently cited authors within each community. ${ }^{145}$ Such as Damanpour, F. (1991). Organizational Innovation: A Meta-analysis of Effects of Determinants and Moderators. Academy of Management Journal 34(3), 555-590; Schumpeter supra note 118; Leadbeater, C. (1997). The Rise of the Social Entrepreneur. Demos 25.

${ }^{146}$ For example M.D. Mumford or Frank Moulaert.

${ }^{147}$ Factiva "is a current international news database produced by Dow Jones, one of the leading global provider of economic and financial information. Factiva.com, from Dow Jones, combines over 35,000 sources to give students, faculty, and librarians access to premium content from 200 countries, in 26 languages. Users have access to a wide range of information from newspapers, newswires, industry publications, websites, company reports, and more. The broad range of content provides both local insight and global perspective on business issues and current events - especially with regard to research requiring current information on companies, industries, and financial markets." See ProQuest. Factiva: About. Online at http://proquest.libguides.com/factiva

148 The search included the terms: "social innovation", "social innovations", "innovation sociale" and "innovations sociales". While the search included publications in all languages, the vast majority were English and French, which was to be expected given that the search terms only referred to the term for social innovation as expressed in these two languages. If a similar search is undertaken for external use, it would be best to find the terms for social innovation used in all 26 languages available via Factiva. For more information on the method of the search, please contact the authors.

${ }^{149}$ Document count by year: 2010 (2264), 2011 (3207), 2012 (3865), 2013 (4648), 2014 (5344), 2015 as of 2 March (906)

${ }^{150}$ A freight company, which was recently bought by Hitachi; social innovation figured into the public explanation of this business decision.

${ }^{151}$ The list is arranged from most to least mentioned. 